Trinity University

Digital Commons @ Trinity

$11-10-1990$

\title{
Compositional Diversity of Late Cenozoic Basalts in a Transect Across the Southern Washington Cascades: Implications for Subduction Zone Magmatism
}

\author{
W. P. Leeman \\ Diane R. Smith \\ Trinity University, dsmith@trinity.edu \\ W. Hildreth \\ Z. Palacz \\ N. Rogers
}

Follow this and additional works at: https://digitalcommons.trinity.edu/geo_faculty

Part of the Earth Sciences Commons

\begin{abstract}
Repository Citation
Leeman, W. P., Smith, D. R., Hildreth, W., Palacz, Z., \& Rogers, N. (1990). Compositional diversity of late Cenozoic basalts in a transect across the southern Washington Cascades: Implications for subduction zone magmatism. Journal of Geophysical Research: Solid Earth, 95(B12), 19561-19582. http://doi.org/ 10.1029/JB095iB12p19561
\end{abstract}

This Article is brought to you for free and open access by the Geosciences Department at Digital Commons @ Trinity. It has been accepted for inclusion in Geosciences Faculty Research by an authorized administrator of Digital Commons@ Trinity. For more information, please contact jcostanz@trinity.edu. 


\title{
Compositional Diversity of Late Cenozoic Basalts in a Transect Across the Southern Washington Cascades: Implications for Subduction Zone Magmatism
}

\author{
William P. Leeman, ${ }^{2}$ Diane R. Smith, ${ }^{2}$ Wes Hildreth, ${ }^{3}$ Zen Palacz,, 45 and Nick Rogers 4
}

\begin{abstract}
Major volcanoes of the Southern Washington Cascades (SWC) include the large Quaternary stratovolcanoes of Mount St. Helens (MSH) and Mount Adams (MA) and the Indian Heaven (IH) and Simcoe Mountain (SIM) volcanic fields. There are significant differences among these volcanic centers in terms of their composition and evolutionary history. The stratovolcanoes consist largely of andesitic to dacitic lavas and pyroclastics with minor basalt flows. IH consists dominantly of basaltic with minor andesite lavas, all erupted from monogenetic rift and cinder cone vents. SIM has a poorly exposed andesite to rhyolite core but mainly consists of basaltic lavas erupted from numerous widely dispersed vents; it has the morphology of a shield volcano. Distribution of mafic lavas across the SWC is related to north-northwest trending faults and fissure zones that indicate a significant component of east-west extension within the area. There is overlap in eruptive history for the areas studied, but it appears that peak activity was progressively older (MSH $(<40 \mathrm{Ka}$ ), IH (mostly $<0.5 \mathrm{Ma}), \mathrm{MA}(<0.5 \mathrm{Ma})$, SIM $(1-4$ $\mathrm{Ma})$ ) and more alkalic toward the east. A variety of compositionally distinct mafic magma types has been identified in the SWC, including low large ion lithophile element (LILE) tholeiitic basalts, moderate LILE calcalkalic basalts, basalts transitional between these two. LILE-enriched mildly alkalic basalts, and basaltic andesites. Compositional diversity among basaltic lavas, both within individual centers as well as across the arc, is an important characteristic of the SWC traverse. The fact that the basaltic magmas either show no correlation between isotopic and trace element components or show trends quite distinct from those of the associated evolved lavas, suggests that their compositional variability is attributable to subcrustal processes. Both the primitive nature of the erupted basalts and the fact that they are relatively common in the SWC sector also imply that such magmas had little residence time in the crust. A majority of the SWC basaltic samples studies are indistinguishable from oceanic island basalts (OIB) in terms of trace element and isotopic compositions, and more importantly, most do not display the typical high field strength element (HFSE) depletion seen in subduction-related magmas in volcanic arcs elsewhere. LILE enrichment and HRSE depletion characteristics of most arc magmas are generally attributed to the role of fuids released by dehydration of subducted oceanic lithosphere and to the effects of sediment subduction. Because most SWC basalts lack these compositional features, we conclude that subducted fluids and sediments do not play an essential role in producing these magmas. Rather, we infer that they formed by variable degree melting of a mixed mantle source consisting mainly of heterogeneously distributed OIB and mid-ocean ridge basalt source domains. Relatively minor occurrences of HFSE-depleted arclike basalts may reflect the presence of a small proportion of slab-metasomatized subarc mantle. The juxtaposition of such different mantle domains within the lithospheric mantle is viewed as a consequence of (1) tectonic mixing associated with accretion of oceanic and island arc terranes along the Pacific margin of North America prior to Neogene time, and possibly (2) a seaward jump in the locus of subduction at about $40 \mathrm{Ma}$. The Cascades are is unusual in that the subducting oceanic plate is very young and hot. We suggest that slab dehydration outboard of the volcanic front resulted in a diminished role of aqueous fluids in generating or subsequently modifying SWC magmas compared to the situation at most convergent margins. Furthermore, with low fluid flux conditions, basalt generation is presumably triggered by other processes that increase the temperature of the mantle wedge (e.g., convective mantle flow, shear heating, etc.).
\end{abstract}

\section{INTRODUCTION}

The Cascade Range is a continental volcanic arc situated along the Pacific Northwest margin of North America. It has been a site of vigorous magmatic activity in response to oblique subduction of the Farallon and Juan de Fuca plates during approximately the last $38 \mathrm{~m} . \mathrm{y}$. [cf. $L u x, 1982 ; \mathrm{Ver}$ planck and Duncan, 1987]. In many respects, the Cascade

\footnotetext{
'Keith-Wiess Geological Laboratories, Rice University, Houston, Texas.

${ }^{2}$ Geology Department, Trinity University, San Antonio, Texas.

${ }^{3}$ U.S. Geotogical Survey, Menlo Park, California.

${ }^{4}$ Department of Earth Sciences, Open University, Milton Keynes. England.

SNow at VG Isotopes Limited, Winsford, Cheshire, England.

Copyright 1990 by the American Geophysical Union.

Paper Number 89JB03490.

0148-0227/90/89J B-03490\$05,00
}

Range has been considered to be a more or less typical subduction-related arc [e.g., McBirney, 1978; McBirney and White, 1982], although petrogenetic studies have largely focused on the more topographically imposing young stratovolcanoes of the High Cascades. We have undertaken petrologic studies of major central volcanoes and nearby basaltic lava fields within an east-west transect across the southern Washington Cascades to document the spatial distribution of magma types in this portion of the arc. This region is an area of transition [Weaver and Malone, 1987] which separates the isolated central volcanoes to the north (Mount Rainier, Mount Baker, and Glacier Peak) from the broad volcanic plateau of the Oregon Cascades to the south which has a widespread and nearly continuous volcanic cover from both large stratovolcanoes (e.g., Mount Hood, Mount Jefferson, Mount Washington, and the Three Sisters) and numerous monogenetic vents [cf. Luedke and Smith. 1982]. Although magmatic activity in the vicinity of the 
Southern Washington Cascades (SWC) transect dates back to at least $36 \mathrm{Ma}$ [cf. Evarts et al., 1987; Korosec, 1987a, b], this paper concentrates on magmatic activity within this part of the Cascades during the past few million years (mainly late Pliocene to Recent) and principally on petrogenesis of the basaltic lavas and implications for subcrustal magmatic processes related to Cascades subduction.

\section{Tectonic Setting of THE SWC}

The Cascades subduction zone is somewhat atypical compared to other convergent margins [Duncan and Kulm, 1989]. There are no deep (>100 km) earthquakes associated with the present Juan de Fuca subduction [Weaver and Baker, 1988], although a subducting slab has been imaged to greater depths by seismic tomography [Rasmussen and Humphreys, 1988]. Because the Juan de Fuca spreading ridge is exceptionally close to the subduction zone, the subducting plate is relatively thin and warm; this factor may explain the paucity of deep earthquakes and may influence the dip angle of the subducting plate as well as the rate of subduction. There is no topographically expressed trench along the convergent margin, possibly because the trench has been filled with terrigenous sediments owing to high rates of sedimentation along the Pacific Northwest margin. Convergence of the Juan de Fuca and North American plates presently occurs at a slow rate (approximately $4 \mathrm{~cm} / \mathrm{yr}$ ) and at an oblique angle (about $\mathrm{N} 50^{\circ} \mathrm{E}$ ) to the continental margin [Riddihough, 1984; Rogers, 1985]; both of these parameters have varied significantly with time [Rea and Duncan, 1986; Verplanck and Duncan, 1987]. Teleseismic imaging of the subducting Juan de Fuca plate suggests that it is segmented and dipping relatively steeply $\left(>45^{\circ}\right)$ beneath the OregonWashington Cascades [Weaver and Michaelson, 1985; Michaelson and Weaver, 1986]. Because of the oblique subduction, the regional stress field is not oriented symmetrically with respect to the subduction zone. Rather, the greatest principal stress corresponds to roughly north-south horizontal compression and the least principal stress to approximately east-west horizontal extension [Zoback and Zoback, , 1980; Smith, 1982; Kim et al., 1986]. Evidence for east-west extension elsewhere in the Cascades arc includes (1) earthquake fault-plane solutions in Northern California [e.g., Klein, 1979], and (2) geological features such as abundance of basaltic lavas, north-south orientation of chains of cinder cones, and major normal faults throughout the range [McBirney, 1978; Hammond, 1979; McKee et al., 1983; Priest, 1983; Bacon, 1985; Smith et al., 1987; Guffanti and Weaver, 1988]. The Oregon High Cascades are actually situated within a N-S trending graben [Taylor, this issue]. A belt of elevated heat flow coincident with this structure presumably reflects shallow magma intrusion and hydrothermal circulation concentrated within an axial extensional zone [Blackwell et al., 1982].

\section{GEOLOGIC SETTING OF THE SWC AND SAMPLE Distribution}

General geologic features of the SWC are shown in Figure 1. The large central volcanoes of Mount St. Helens (MSH) and Mount Adams (MA) and the shieldlike Simcoe (SIM) (or Indian Rock) volcano define an easterly trend some $100 \mathrm{~km}$ in width. The exposed basement consists mainly of Cenozoic volcanic and sedimentary rocks. Each of these volcanoes comprises a variety of magma types ranging from basalt to rhyodacite [Hoblitt et al., 1980; Hildreth and Fierstein, 1985; Ort et al., 1983]. Distributed among them are the Indian Heaven (IH) and numerous smaller lava fields, small shield volcanoes, and monogenetic vents comprising mainly basattic lavas [e.g., Hammond and Korosec, 1983]. Many of the latter vents are distributed in roughly NNE to NNW trending alignments or fissure systems that presumably are per. pendicular to the direction of least principle horizontal stress [e.g., Nakamura, 1977]. Loci of the large stratovolcanoes straddle such structures, and most notably Mount St. Heleas [C.S. Weaver et al., 1987] and Mount Hood [Williams et al., 1982] appear to be situated above zones of local crusta extension along active NW trending strike-slip zones.

Mount St. Helens has been intermittently active during the last 36,000 years [Mullineaux, 1986], during which time it produced predominantly dacitic magmas [Smith and Leeman, 1987]. In the last $\sim 2000$ years, its eruptive products have become more diverse, ranging from basalt to rhyodacite. However, true basaltic lavas were produced onty during the Castle Creek eruptive period (2200-1700 years B.P. [Hoblitt et al., 1980]). Somewhat older (about 690,000 to 8,000 years B.P. [Hammond and Korosec, 1983]) basaltic to andesitic lavas erupted from smaller vents in the vicinity (e.g., Marble Mountain, West Crater, Soda Peak, and Trout Creek Hill; see Figure 1); some of these vents lie along the NW trending Mount St. Helens seismic zone [C.S. Weaver et al., 1987].

The Indian Heaven and King Mountain-Mount Adams volcanic fields are associated with NNE to NNW trending structures (fissures or normal fault zones) that are delineated by alignments of vents. Most volcanic activity in the Indian Heaven field postdates the last magnetic reversal at 670,000 years. B.P. [Hammond and Korosec, 1983; M. A. Korosec, personal communication 1989]; these rocks are predominantly primitive basalts, although a few basaltic andesites and andesites are present. Most eruptive products of Mount Adams (a composite stratovolcano) are younger than about 450,000 years B.P. [Hildreth and Fierstein, 1985]; they range in composition from basalt to rhyodacite, although the basalts typically erupted from monogenetic or shield vents distributed on the flanks of the stratovolcano. Due south of Mount Adams, and east of Mount Hood, the NNE trending Hood River fault zone in northern Oregon is associated with a small field of Plio-Pleistocene basaltic lavas. East of Mount Adams, the Plio-Pleistocene Simcoe (Indian Rock) volcano is a large shieldlike structure with exposures of dacites and rhyolites in its dissected core [Sheppard, 1967]. However, its surrounding flanks are blanketed by basaltic lavas which erupted from numerous fissures, cinder cones, and small shield vents that define either N-S or NNW trending aligat ments. Available K-Ar ages indicate that nearly all Simcoe lavas are older than $1 \mathrm{Ma}$; most range between 2 and $4 \mathrm{Ma}$ [Farooqui et al., 1981; Luedke and Smith, 1982; Phillips et al., 1986; Anderson, 1987a, b].

Although only approximate estimates of magma volumes are available for this sector of the Cascades arc [cf. Sherrod and Smith, this issue], it is clear that basaltic lavas are common except within the large stratovolcanoes, and even there basaltic lavas occur in significant volumes [cf. Hammond and Korosec, 1983]. For comparison, basaltic rocks are also abundant in the southern Cascades [Luedke 


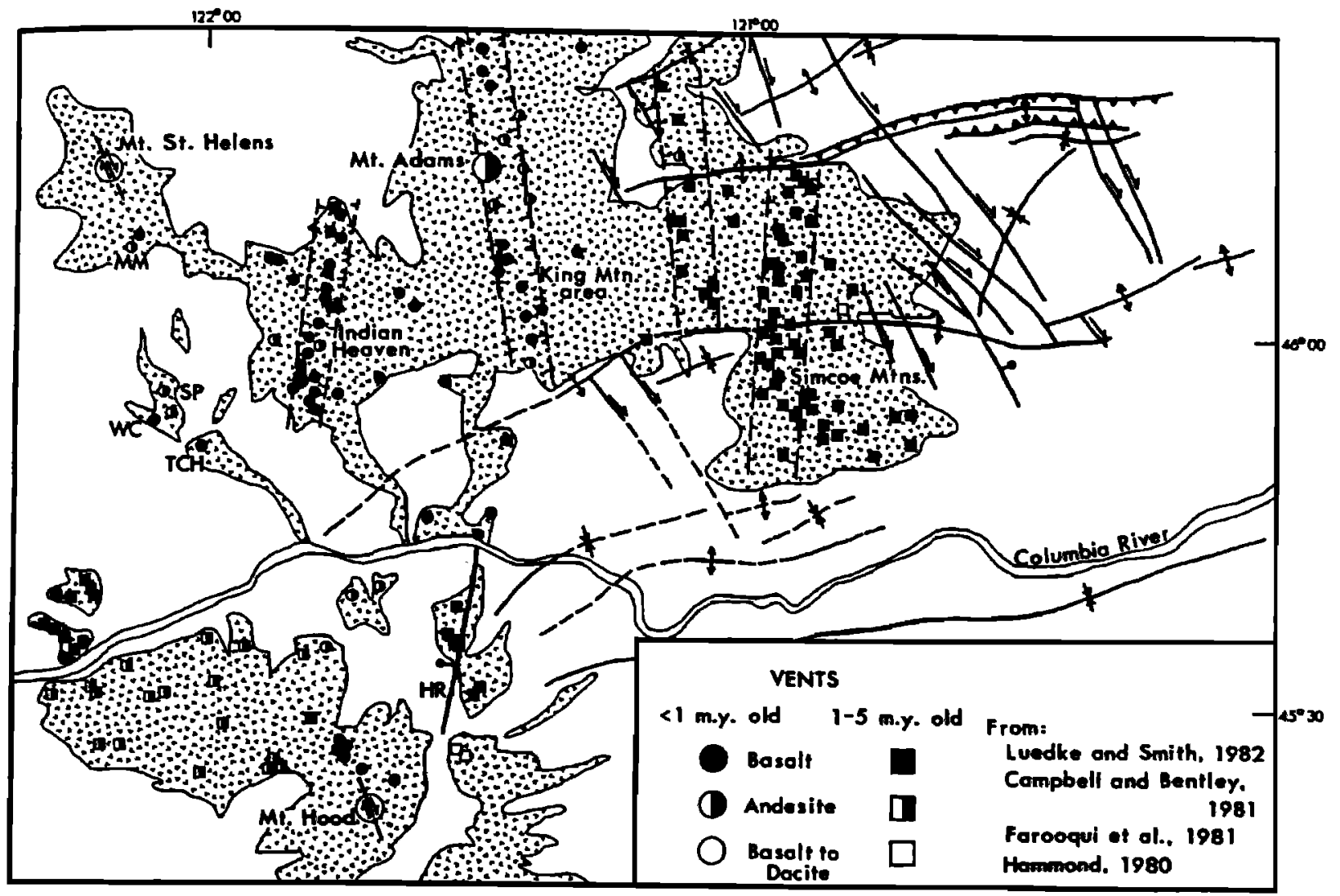

Fig. 1. Geologic setting of the SWC traverse showing extent of late Pliocene to Recent volcanic rocks (stippled areas) and locations of major vents [from Leudke and Smith, 1982]. Miscellaneous sampling localities indicated by letters include Marble Mountain (MM), Soda Peak (SP), West Crater (WC), Trout Creek Hill (TCH), and Hood River valley (HR). Conspicuous vent alignments (outlined by dashed lines) are believed to be fault-controlled. Major structures (indicated by conventional symbols) offsetting Miocene to Pliocene age volcanic deposits include ENE trending folds and thrust faults, NW trending strike-slip faults, and north trending normal faults [after Hammond, 1980; Campbell and Bentley, 1981; Farooqui et al., 1981]. These structural elements are compatible with N-S regional compression $\left(\sigma_{1} \mathrm{~N}-\mathrm{S}\right)$ and are distinct from Neogene structural patterns of the Basin and Range province ( $\sigma_{1}$ vertical).

Smith, 1982; McKee et al., 1983; Hughes and Taylor, 1986; Walker and Naslund, 1986], and it is estimated that they comprise as much as $85 \%$ by volume of the Tertiary to modern Oregon Cascades [McBirney and White, 1982]. In the SWC traverse, basaltic volcanism was not common prior to Pliocene time; thereafter, basaltic magmatism is characteristic of the entire traverse, although such lavas are more voluminous toward the east. It is unclear whether this relation reflects fundamental differences in the supply of basaltic magma across the transect, or the possibility that eruption efficiency of mafic magmas is somehow proportional to the lifetime of the eruptive centers. The main objective of this paper is to provide a concise overview of spatial variations in magma composition based on representative samples collected from all of the localities discussed.

\section{Analytical Methods}

Major element compositions were determined for more than 150 whole rock samples using a combination of $X$ ray fuorescence (XRF) spectrometry and inductively coupled plasma optical emission spectroscopy. Many of these rocks were also analyzed for trace element contents using the aforementioned methods along with instrumental neutron activation spectrometry. All analytical methods used are described by Smith and Leeman [1987], and error estimates for each element are given therein. Briefly, on the basis of replicate analyses, accuracy and precision of major element contents are estimated to range between 1 and $2 \%$, and of most trace elements between 2 and $10 \%$ of the amount reported. For elements determined by more than one method, either averages or results by the most precise method are reported. Major element analyses are reported on a "dry" basis recalculated to $100 \%$ with all iron as FeO*. Isotopic compositions of $\mathrm{Sr}, \mathrm{Nd}$, and $\mathrm{Pb}$ were measured using VG Isotopes S4E and Finnigan-MAT 251 mass spectrometers at the Open University, England. Ratios are normalized to correct for mass fractionation as follows: ${ }^{86} \mathrm{Sr} /{ }^{88} \mathrm{Sr}=0.1194,{ }^{146} \mathrm{Nd} /{ }^{144} \mathrm{Nd}=0.7219$. Pb isotope ratios were corrected for $-0.1 \%$ fractionation per amu based on replicates of the NBS-981 common lead standard. Accuracy of the reported ratios is about $\pm 0.00003(0.004 \%)$ or better for ${ }^{87} \mathrm{Sr} /{ }^{86} \mathrm{Sr}, \pm 0.00002(0.003 \%)$ or better for ${ }^{143} \mathrm{Nd} /{ }^{144} \mathrm{Nd}$, and $\pm 0.02(0.1 \%)$ or better for all lead isotope ratios; internal precision of the analyses is usually better than these estimates. The ${ }^{87} \mathrm{Sr} /{ }^{86} \mathrm{Sr}$ ratios are reported relative to values of 0.70800 and 0.71028 for the Eimer \& Amend and NBS-987 standards, respectively; analyses of BCR-1 during the 
TABLE 1. Distribution of Magma Types in Major Eruptive Centers of the SWC

\begin{tabular}{|c|c|c|c|c|}
\hline $\begin{array}{c}\text { Compositional } \\
\text { Types }\end{array}$ & $\begin{array}{l}\text { St. } \\
\text { Helens }\end{array}$ & $\begin{array}{l}\text { Indian } \\
\text { Heaven }\end{array}$ & Adams & Simcoe \\
\hline \multicolumn{5}{|l|}{ Basalts } \\
\hline Tholeiitic & - & $x x$ & $x$ & - \\
\hline Transitional & $\mathrm{x}$ & $x$ & $\mathrm{x}$ & - \\
\hline Calcalkalic & $\mathrm{x}$ & $\mathrm{xx}$ & $x x$ & - \\
\hline Alkalic & - & - & $\mathrm{x}$ & $x x$ \\
\hline $\begin{array}{l}\text { Basaltic } \\
\text { andesites }\end{array}$ & $x$ & $x$ & $x$ & - \\
\hline Andesites & $x x$ & $\mathrm{x}$ & $x x$ & $x ?$ \\
\hline $\begin{array}{l}\text { Dacites, } \\
\text { rhyodacites, } \\
\text { rhyolites }\end{array}$ & $x x$ & - & $x$ & $\mathrm{x}$ \\
\hline
\end{tabular}

Dash, not recognized; $x$ ?, present but volume unknown; $x$, present to common; $x x$, common to abundant.

course of this study averaged 0.70500 . The ${ }^{143} \mathrm{Nd} /{ }^{144} \mathrm{Nd}$ ratios are reported relative to values of 0.51182 and 0.51264 for La Jolla Nd oxide and BCR-1, respectively. Oxygen isotopic analyses were measured on whole rock and plagioclase separates at Menlo Park (MA), University of Wiscon$\sin (\mathrm{IH})$, the Geological Survey of Japan (MSH), and Southern Methodist University (SIM). The $\delta^{18} \mathrm{O}$ ratios are reported relative to SMOW with values of $9.6 \%$ for the NBS-28 quartz standard; duplicate analyses indicate precision of about $\pm 0.1 \%$. Results of the isotopic analyses are shown in Figures 8-12, and representative analyses are given in Table 2. For comparison, only a few $\mathrm{Pb}, \mathrm{Nd}$, and $\mathrm{Sr}$ isotopic analyses have been published previously for SWC volcanoes [Church and Tilton, 1973; Church, 1976; Halliday et al., 1983]; a survey of ore $\mathrm{Pb}$ data [Church et al., 1986] includes samples from the SWC.

\section{Mineralogy of Lavas From the SWC}

Detailed studies of petrology, mineralogy, and of the magmatic evolution of the individual eruptive centers have been [e.g., Smith and Leeman, 1987] or will be presented elsewhere. Table 1 briefly summarizes the distribution of magma types recognized at the major SWC volcanic centers; criteria for subdividing the basaltic variants are discussed below. Those from the Simcoe field are notably distinct in that they commonly carry conspicuous phenocrysts of plagioclase, olivine, and occasionally clinopyroxene; in addition, small xenoliths of spinal lherzolite and diverse crustal lithologies were found in some of these lavas. Basalts from the other localities also tend to be porphyritic (plagioclase and olivine \pm rare clinopyroxene), but their phenocrysts usually are relatively small (usually no more than a few millimeters in length); however, basalts with large (up to a few centimeters) plagioclase megacrysts are present at Indian Heaven. Hydrous phenocrysts are typically absent from the mafic lavas. The only known exception is the notable occurrence of rare, partially resorbed amphibole phenocrysts in one basaltic unit from the Indian Heaven field (Berry Mountain unit of Hammond and Korosec [1983]). Andesitic and dacitic lavas and pyroclastic deposits dominate the main stratovolcanoes. These are typically porphyritic with ubiquitous plagioclase phenocrysts and assorted combinations of mafic phenocrysts including clinopyroxene and orthopyroxene, amphibole (hornblende and/or cum- mingtonite), Fe-Ti oxides, and olivine (rare). Biotite and $\mathrm{K}$-feldspar occur in some rhyodacites and rhyolites (e.g. SIM).

\section{Geochemistry of Lavas From the SWC}

Perhaps the most important observation of this study is the relatively wide range in compositions of basaltic lavas erupted within a relatively small region within the Cascade arc. Selected analyses are presented in Table 2 to illustrate the magmatic variants so far recognized; complete data win be presented in separate papers discussing each volcanic center. Analyses from MSH include the "transitional" Cave Basalt (DS-27, 82-56) from the south flank, calcalkalic be salts (DS-6, DS-9, and H-SH17 [from Halliday et al., 1983]) and basaltic andesite (DS-72) from the (now obliterated) northern flank, andesitic (SH-25) and dacitic (SH-24) tephras; all of these samples represent the Castle Creek eruptive episode (1700-2200 years B.P.). The most evolved MSH magmas are represented by a rhyodacitic lava from East dome (DS-62); further analyses of more evolved MSH rocks are given by Hoblitt et al. [1980], Halliday et al. [1983], and Smith and Leeman [1987]. The dominantly basaltic IH field has been described by Hammond [1980] and Hammond and Korosec [1983], who mapped and named many of the flow units. Analyses are given for low- $K$ tholeiitic basalts (DS80A, DS15A-80), calc-alkalic basalts (DS9A-81, DS3B-80), basaltic andesites with relic amphibole (DS69A-80, DS42-81, and DS23B-81; all from Berry Mourtain), and an olivine andesite (DS-63) which is the most evolved sample known from the IH field. Analyses for Mount Adams include low-K tholeiites (83-49, MA434), calc-alkalic basalts (82-31, 82-26, MA226, MA421, MA20), a basaltic andesite (MA148), and the Holocene Aiken andesite flow (82-24). Additional major element analyses for lavas from the Mount Adams area are given by Korosec [1987a] and Anderson [1987a]. Samples from the SIM field include $\sim 1-4 \mathrm{Ma}$ basalts from peripheral vents from the west (L8365, L83-97), southeast (L83-92, L83-94), and south (L83-67, Maryhill flow) and a dacite (L84-65) and rhyolite (L84-67) from the eroded core of the volcano near Indian Rocks. Major element analyses of additional SIM lavas are given by Ort et al. [1983] and Anderson [1987a]. Not only are there differences among the various eruptive centers sampled, but there are also significant variations within single eruptive centers. The wide compositional spectrum of roughly contemporaneous basaltic magmas reveals that petrogenetic processes are complex and that not all of these magmas were derived from common source materials. Second, most of the young Cascades basalts studied differ from those in other volcanic arcs; in many respects they more closely resemble oceanic (or within-plate) basalts despite their obvious association with an active subduction complex.

\section{Major Element Compositions and Definitions of Basalt Types}

Approximately 150 major element analyses are compared in Figure 2, which shows the discriminant diagrams of Miyashiro [1974] and Gill [1981]. The AFM (alkalies-FeO*$\mathrm{MgO}$ ) diagram (not shown) of Irvine and Baragar [1971] was used to subdivide the mafic lavas into tholeiitic and calcatkalic magma series. Although most samples studied are broadly calc-alkalic, tholeiitic basalts occur at IH and MA. 
and transitional basalts occur at MSH. Figure 3 shows that besalts from $\mathrm{MSH}, \mathrm{IH}$, and $\mathrm{MA}$ have relatively high $\mathrm{Mg}$ \# $\left\{100 \times\right.$ molar $\mathrm{MgO} /\left[\mathrm{MgO}+\mathrm{FeO}^{*}\right]$; note that these are minimal values as some fraction of the iron actually occurs as $\mathrm{Fe}_{2} \mathrm{O}_{3}$ ); in particular, some from $\mathrm{IH}$ resemble high-Mg Aleutian basalts ( $\mathrm{Mg} \# \sim 70$ [cf. Gust and Perfit, 1987]). The basalts (and andesites) have relatively high alumina contents (typically between 16 and $18 \%$ ). It can be noted in this diagram that the basaltic lavas with $\mathrm{Mg}$ \# greater than 55 conform rather closely to an idealized olivine + clinopyroxene fractionation trend. In fact, many of these basalts do contain phenocrystic olivine and clinopyroxene along with plagioclase, implying evolution at relatively high pressure $(>$ -8 kbar [Gust and Perfit, 1987]). However, alkali contents vary considerably in SWC basalts $\left(0.2-2.4 \% \mathrm{~K}_{2} \mathrm{O}\right.$; Figure 2b). The SIM basalts stand out in terms of their comparatively high alkali contents; they comprise alkalic and subalkalic groups (cf. Figure $2 a$ ) the most potassic of which is characterized by normative nepheline. Most other SWC basalts are hypersthene normative.

Evolved lavas from MSH, MA, and SIM volcanoes consist of medium- to high-K andesites, dacites, and rhyolites. Volcanic rocks from each center define coherent compositional trends on silica variation diagrams (cf. Figure 2), but a few MSH "dacites" (oxidized pumices) have conspicuously high alumina (Figure 3 ) and relatively low silica contents. In terms of most other major and trace element constituents and their mineralogy, these rocks are indistinguishable from other MSH dacites. Smith and Leeman [1987] suggested that these features may reflect alteration processes (as opposed to accumulation of plagioclase phenocrysts, for example); Halliday et al. [1983] also report one such analysis. In general, alkalinity of SWC magma suites increases eastward with distance from the subduction zone, as does the maximum silica enrichment attained. However, there is considerable variability among IH and MA mafic lavas which range from low- $K$ tholeitic to high-K calcalkalic basalts. Inspection of basalt analyses in Table 2 having comparable $\mathrm{MgO}$ contents (e.g., 6\%) shows that the major and trace element compositions do not covary in any systematic fashion.

\section{Trace Element Compositions}

Representative trace element patterns for SWC mafic lavas are shown in Figure 4 normalized to the "primordial mantle" values of Wood [1979]. These projections facilitate comparisons of elements that display similar degrees of "incompatibility" relative to dominant mantle (or phenocryst) mineral assemblages. Most basaltic lavas from MSH, MA, and SIM, and low-K IH basalts have relatively smooth convex-upward trace element profiles characteristic of oceanic island basalts (OIBs). Only a few IH (e.g., DS23B-81, DS3B-80; Table 2) and MA lavas display relative depletions in high field strength elements (HFSE; notably Nb and Ta) which are characteristic of many arc magmas [Perfit et al., 1980; Gill, 1981; Pearce, 1983; Briqueu et al., 1984; B. L. Weaver et al., 1987]. It is perhaps more accurate to note that the latter samples are distinctive in that $\mathrm{Nb}, \mathrm{Ta}$, and $\mathrm{Ti}$ seem to be depleted with respect to all the other incompatible elements except the heavy REE, Y, and possibly P; another unusual aspect of these lavas is that there is no significant enrichment of LIL or B relative to LREE (i.e., Ba/La and $B / L$ are similar to ratios in other SWC basalts). These distinctions are further emphasized in Figure 5 wherein the majority of SWC basalts (and several from the Oregon High Cascades [Hughes and Taylor, 1986]) have Ta/Yb-Th/Yb ratios that plot along a so-called "mantle array" defined by mid-ocean ridge (MORB) and oceanic island (OIB) basalts. Only a few mafic lavas and assorted evolved lavas actually plot in the field of volcanic arc magmas. Those SWC basalts conforming to the mantle array display other similarities to OIB-like magmas: e.g., low boron contents ( $1-4$ ppm [Leeman, 1987]) and $\mathrm{Ba} / \mathrm{La}$ (<18 for most [Perfit et al., 1980; Morris and Hart, 1983]) compared to basalts from virtually all other modern arcs. None of the SWC basalt types analyzed so far have detectable concentrations of ${ }^{10} \mathrm{Be}$ [Morris et al., 1989]. In these regards, the modem Cascade arc appears to be unusual. The question arises as to whether these features refiect unusual conditions of magma genesis and, if so, has this been a persistent situation or a relatively recent turn of events.

Another remarkable feature of the SWC basalts is their compositional diversity, which is further illustrated in Figure 6 , where $\mathrm{Ba}$ and $\mathrm{Nb}$ are plotted versus $\mathrm{SiO}_{2}$. First, the ranges in $\mathrm{Ba}(-20 \times), \mathrm{Nb}(\sim 12 \times)$, and $\mathrm{Ba} / \mathrm{Nb}(\sim 9 \times)$ are substantial. The SIM alkalic basalts resemble many OIBs in having high $\mathrm{Nb}(20-60)$ and low $\mathrm{Ba} / \mathrm{Nb}(10-20)$. Low-K tholeiitic basalts from $\mathrm{IH}$ and MA have the lowest $\mathrm{Ba}$ and $\mathrm{Nb}$ but have $\mathrm{Ba} / \mathrm{Nb}$ ratios which overlap with those in the alkalic basalts. Because both $\mathrm{Ba}$ and $\mathrm{Nb}$ are strongly partitioned into basaltic magmas during melting and crystallization processes, it is unlikely that the $\mathrm{Ba} / \mathrm{Nb}$ ratio can be easily fractionated [cf. Hofmann, 1988]. Thus there may be some form of petrogenetic linkage among all of the SWC basalts (e.g., they could represent variable degrees of fusion of common source materials). Second, the HFSE-depleted IH lavas have elevated $\mathrm{Ba}$ and relatively high $\mathrm{Ba} / \mathrm{Nb}$ ratios (30-90); these lavas are unlikely to be related to the other basalt types via closed system evolution or by partial melting of similar sources. Some mechanism is required to explain both their $\mathrm{Nb}$ depletion and their Ba enrichment. $\mathrm{Nb}$ depletion is presumably "source-related" as it is very difficult to conceive of magma contamination models that can produce this effect while retaining a basaltic bulk composition [cf. Hickey et al., 1986]. Ba/Nb possibly can change with degree of melting, so long as the source contains a minor phase that preferentially incorporates Nb [cf. Reagan and Gill, 1989].

It is also useful to consider how these elements are distributed in more evolved lavas to appreciate the efficacy of various petrogenetic processes. Figure 6 clearly shows that MA and MSH have distinctive evolutionary patterns. At $\mathrm{MSH}, \mathrm{Ba} / \mathrm{Nb}$ increases sixfold from basalts to rhyodacites suggesting that $\mathrm{Nb}$ is more compatible than $\mathrm{Ba}$. This is apparently the case at MSH, as Smith and Leeman [1987. Table 7] calculated average bulk $D_{\mathrm{Ba}}(0.54)<D_{\mathrm{Ta}}(0.86)$ for MSH whole rock-glass pairs which imply that contents of both $\mathrm{Ba}$ and $\mathrm{Ta}$ (geochemically similar to $\mathrm{Nb}$ ) should increase slightly as crystallization proceeds. However, the striking decrease in $\mathrm{Nb}$ contents with increasing $\mathrm{SiO}_{2}$ at MSH is inconsistent with the inferred Nb distribution coefficient (assumed to be similar to that of $\mathrm{Ta}$ ), thus ruling out simple fractionation models. A more reasonable hypothesis is that MSH dacites represent crustal melts which have no derivative relationship to the associated basalts [Smith and Leeman, 1987]. On the other hand, MA evolved lavas show progressive increases in both $\mathrm{Ba}$ and $\mathrm{Nb}$, and a slight 
TABLE 2. Representative Lavas From the

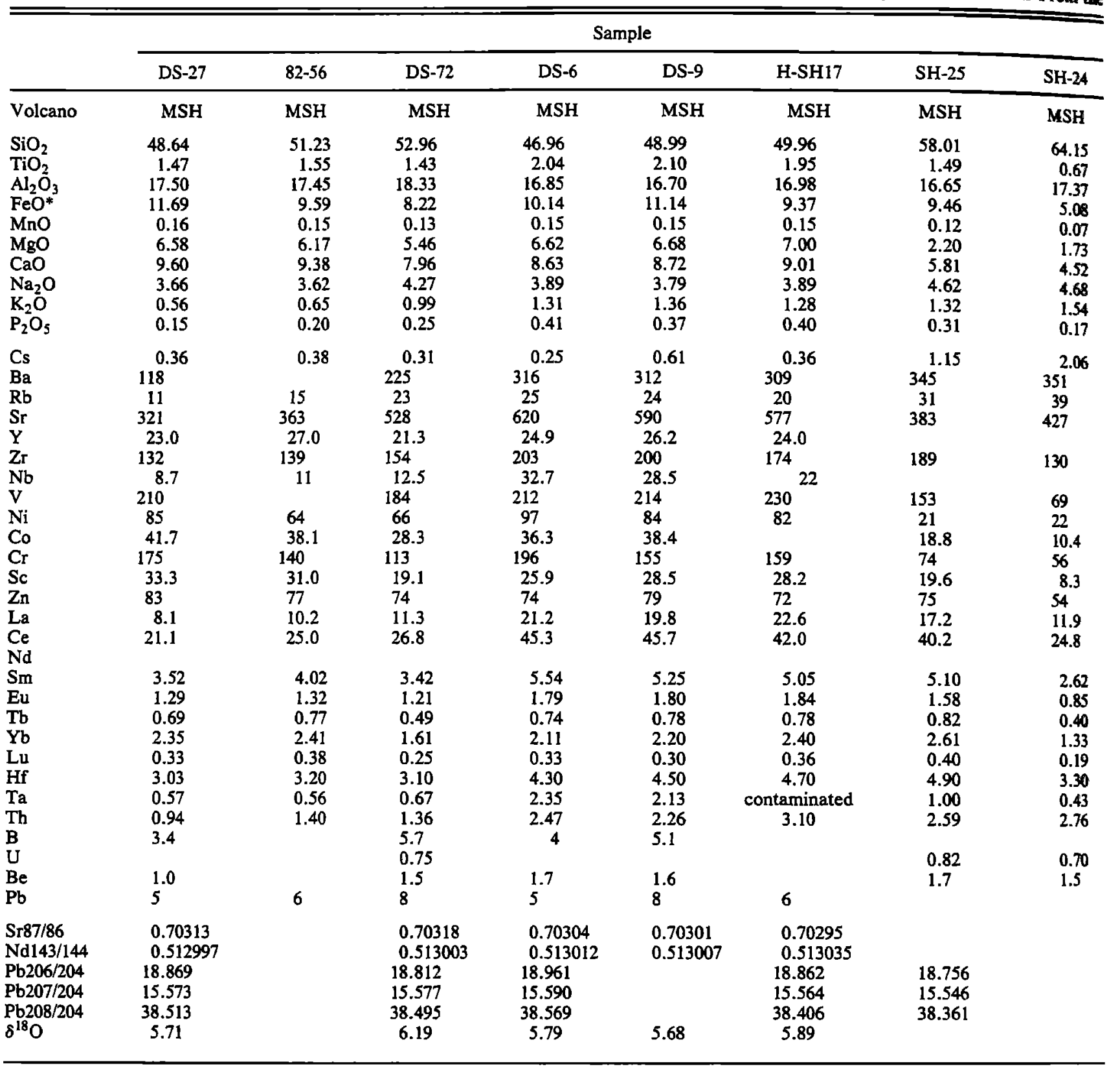

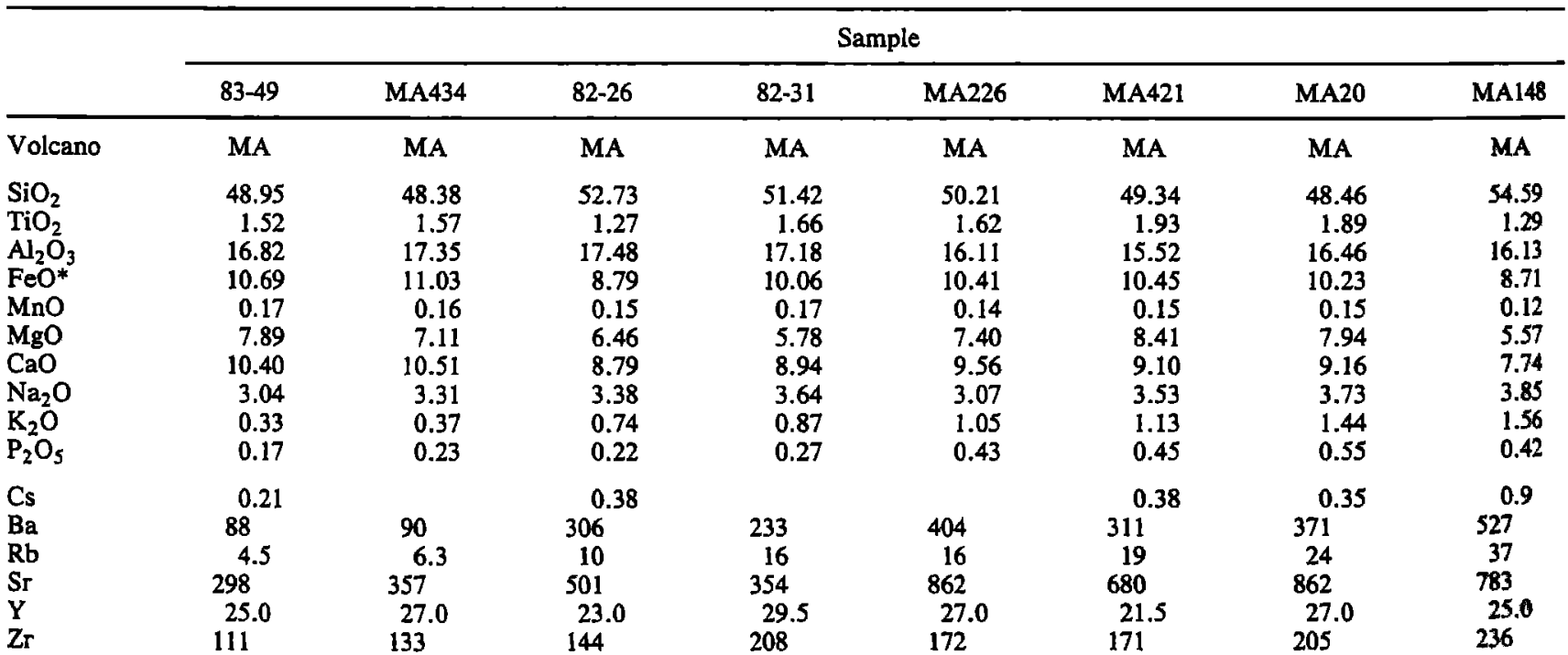


Southern Washington Cascades

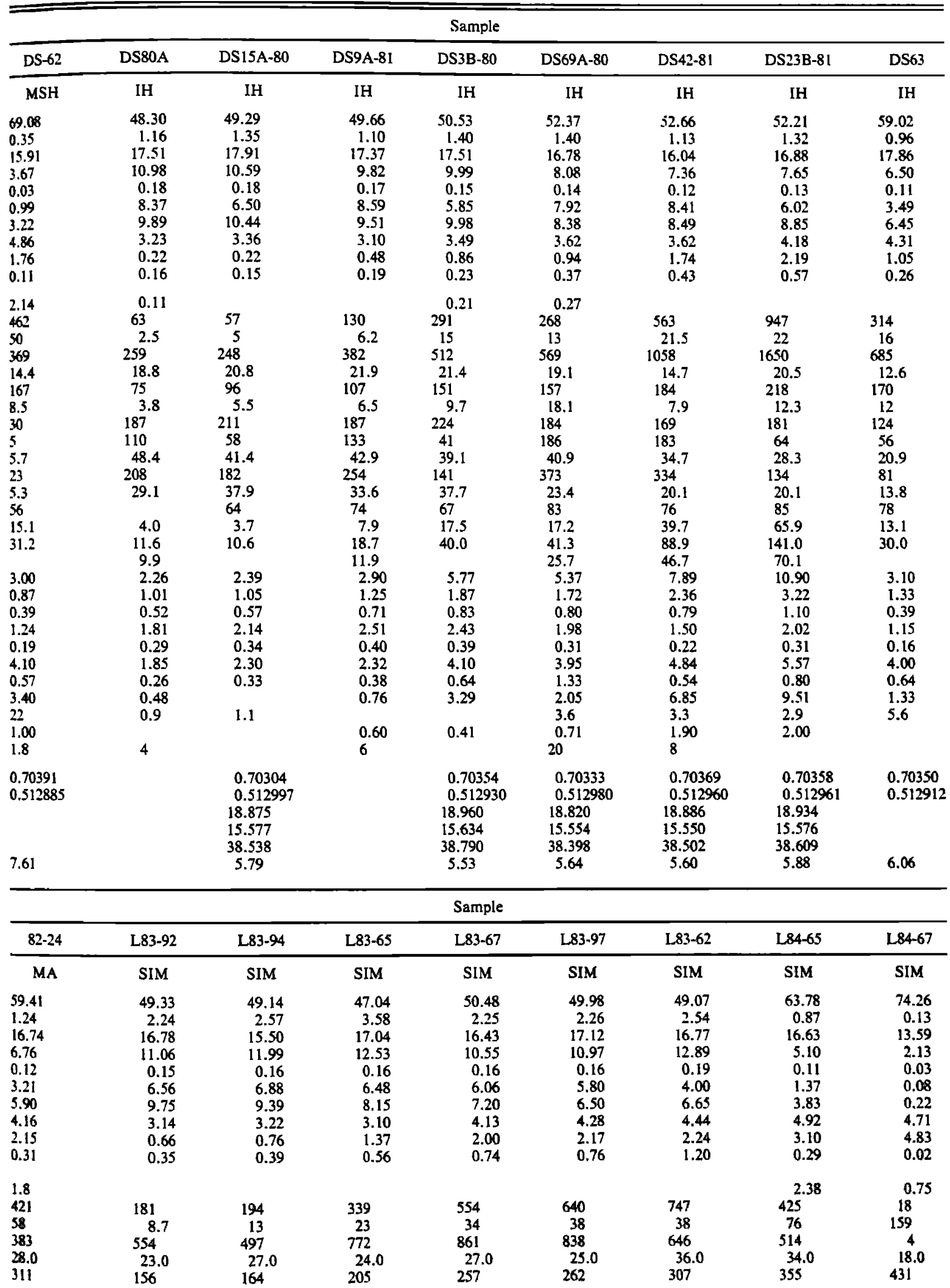


TABLE 2.

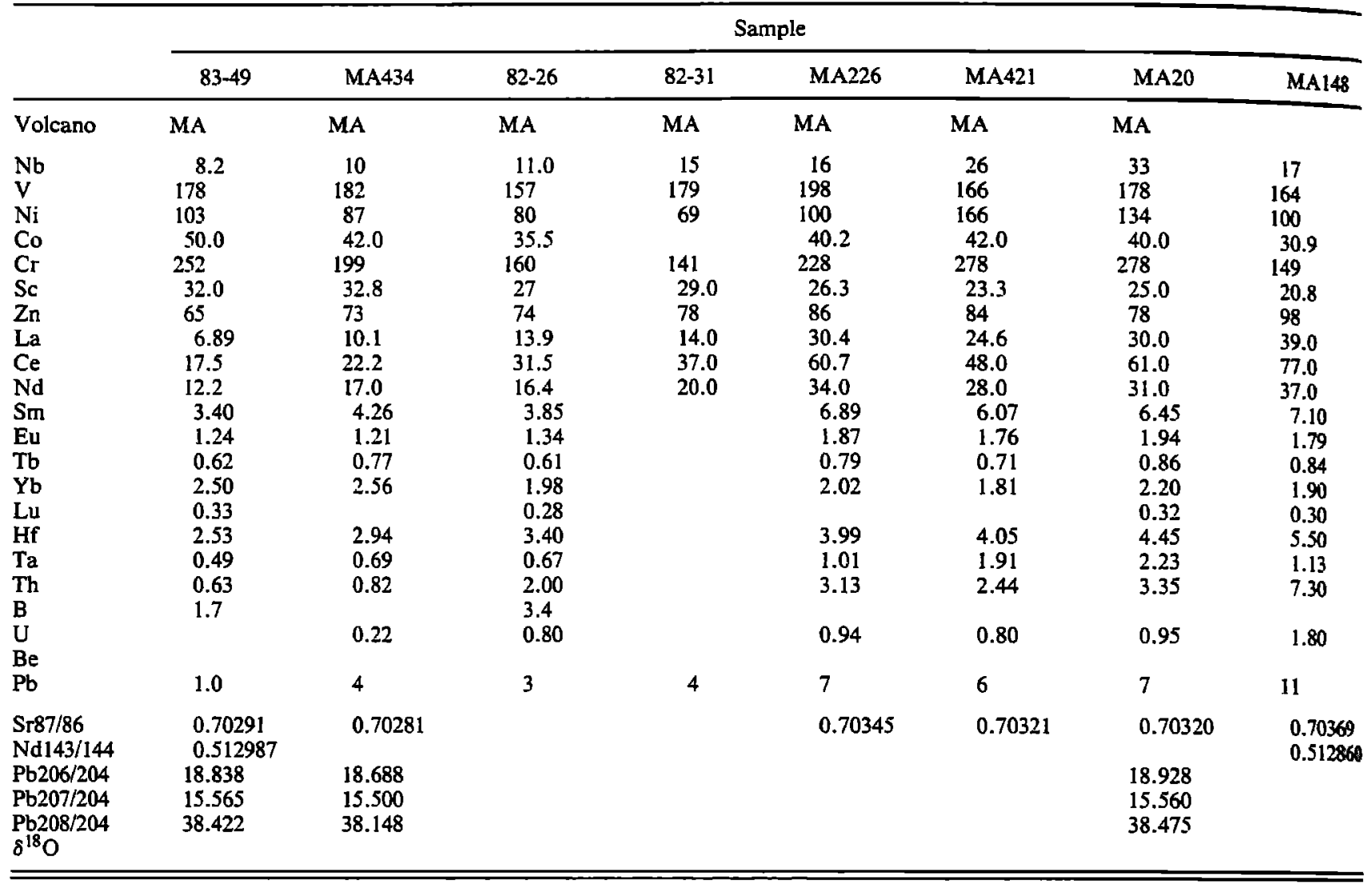

decrease in $\mathrm{Ba} / \mathrm{Nb}$ with increasing $\mathrm{SiO}_{2}$, all of which seem more consistent with crystal fractionation processes. This is not to say that there is an obvious linkage between evolved lavas and any of the associated basalts, which are themselves somewhat variable in composition. In passing, the strong $\mathrm{Ba}$ depletion seen in the SIM rhyolite is suggestive of extreme fractionation involving alkali feldspar; the high $\mathrm{Nb}$ and very low $\mathrm{Ba} / \mathrm{Nb}$ ratio in this rock do not support significant involvement of crust (which typically has low Nb and high $\mathrm{Ba} / \mathrm{Nb}$ ).

Variation in $\mathrm{Ba}$ and $\mathrm{Nb}$ contents is displayed directly (Figure $7 a$ ), and also as normalized to $\mathrm{Zr}$, which is a slightly more compatible trace element (Figure $7 b$ ). For basaltic magmas, this element ratio plot minimizes scatter related to variations in degree of crystallization or partial melting. In both plots two distinct trends emerge for the SWC basaltic lavas. First, a "mantle array" is again evident, here embellished by data from representative samples of OIB (e.g. Tristan da Cunha [B. L. Weaver et al., 1987) and normal MORB (NMORB) [Le Roex et al., 1983]. These comparative samples were chosen simply because they approach extremes in $\mathrm{Ba}$ and $\mathrm{Nb}$ contents of oceanic basalts, but the light stippled field in Figure $7 b$ represents a compilation of several hundred Pacific island basalts (W. P. Leeman, unpublished data and literature survey, 1990). $\mathrm{Ba} / \mathrm{Nb}$ for this group of SWC basalts is $\sim 11.5$. Second, a small number of HFSE-depleted IH basalts (and a few miscellaneous basalts from West Crater and the Hood River valley) define a distinct linear array which trends toward a high $\mathrm{Ba} / \mathrm{Nb}$ component. Strong large ion lithophile element (LILE) versus HFSE correlations in both of these arrays could reflect some form of mixing between compositionally distinct endmembers. Either melting of previously mixed sources or contamination of ascending magmas would be reasonable causes for the observed near-linear arrays. Simple variations in degree of melting or crystallization are plausible causes for the different trends only if the two arrays result from differential involvement of a Nb-buffering residual phase.

The SWC basalts which conform to the "mantle array" defined by OIB and MORB analyses could represent melting of a mixed mantle material comprising OIB and MORB source components, or possibly magma-wall rock interac. tions involving such mantle components. The absence of significant LILE/HFSE fractionations in most young SWC basalts is unusual for volcanic arc magmas. On the other hand, the rarer HFSE-depleted basalts could result from combined fractional crystallization and assimilation of a high $\mathrm{Ba} / \mathrm{Nb}$ contaminant; however, rocks similar to estimated average crustal composition [Taylor and McLennan, 1985] would be inadequate contaminants. Ba enrichment in are magmas commonly has been attributed to subduction of Ba-rich pelagic sediments [cf. Kay, 1984]. As an example, in Figure $7 b$ a mixing vector is shown that heads toward an estimated average composition for Pacific pelagic sediments (e.g., "PAWMS" composition of Hole et al. [1984]). The data for SWC andesites and more evolved samples are possibly consistent with assimilation of Ba-rich sediments because $\mathrm{SiO}_{2}, \mathrm{Ba}$, and $\mathrm{Ba} / \mathrm{Zr}$ are all positively correlated these rocks. Some other explanation seems required for the IH basaltic lavas. As pointed out by many authors [e.g., Pearce, 1983; Hole et al., 1984; Tatsumi et al., 1986], hit LILE/HFSE ratios could also reflect source metasomatisn 
(continued)

\begin{tabular}{|c|c|c|c|c|c|c|c|c|}
\hline \multicolumn{9}{|c|}{ Sample } \\
\hline $82-24$ & L83-92 & L83-94 & L83-65 & L83-67 & L83-97 & L83-62 & L84-65 & L84-67 \\
\hline MA & SIM & SIM & SIM & SIM & SIM & SIM & $\operatorname{SIM}$ & SIM \\
\hline 25 & 21 & 22 & 37 & 50 & 53 & 57 & 34 & 76 \\
\hline 114 & 173 & 186 & 195 & 129 & 106 & 80 & 49 & 3 \\
\hline 29 & 80 & 87 & 33 & 137 & 85 & 18 & 7 & 4 \\
\hline 20.0 & 42.3 & 45.5 & 46.0 & 38.1 & 36.9 & 32.1 & 6.7 & 0.3 \\
\hline 32 & 160 & 159 & 32 & 144 & 125 & 29 & 13 & 6 \\
\hline 17.0 & 24.1 & 24.8 & 18.4 & 15.8 & 15.0 & 14.4 & 6.6 & 0.4 \\
\hline 73 & 102 & 106 & 101 & 96 & 98 & 124 & 78 & 114 \\
\hline 28.7 & 16.1 & 17.1 & 26.2 & 37.8 & 40.5 & 49.1 & 38.6 & 21.1 \\
\hline 59.9 & 35.6 & 37.5 & 56.1 & 76.0 & 78.4 & 99.4 & 84.2 & 40.3 \\
\hline 26.3 & 22.0 & 23.0 & 32.0 & 38.0 & 39.0 & 54.0 & 39.0 & 16.4 \\
\hline 5.69 & 5.51 & 6.13 & 6.68 & 7.91 & 7.96 & 11.00 & 7.73 & 3.61 \\
\hline 1.50 & 2.01 & 2.18 & 2.36 & 2.67 & 2.61 & 3.49 & 1.85 & 0.16 \\
\hline 0.77 & 0.86 & 1.06 & 1.00 & 1.12 & 1.01 & 1.46 & 1.15 & 0.70 \\
\hline 2.43 & 1.82 & 2.16 & 1.98 & 2.15 & 2.07 & 2.90 & 3.00 & 2.50 \\
\hline 0.37 & 0.28 & 0.32 & 0.28 & 0.34 & 0.31 & 0.44 & 0.48 & 0.38 \\
\hline 6.40 & 3.90 & 4.27 & 4.80 & 5.71 & 5.91 & 7.02 & 7.60 & 12.80 \\
\hline 1.60 & 1.39 & 1.58 & 2.70 & 3.52 & 3.82 & 4.25 & 2.07 & 4.45 \\
\hline 6.80 & 1.70 & 1.67 & 2.64 & 4.18 & 4.22 & 4.61 & 9.80 & 18.70 \\
\hline 12 & 2 & 2.2 & 1.2 & 2 & 1.5 & & & \\
\hline 2.20 & 0.40 & 0.70 & 0.70 & 1.50 & 1.50 & 1.40 & 3.00 & 4.30 \\
\hline \multirow[t]{7}{*}{7} & 8 & 5 & 5 & 7 & 8 & 5 & 7 & 12 \\
\hline & 0.70289 & 0.70 .287 & 0.70316 & 0.70303 & 0.70302 & & & \\
\hline & 0.512958 & 0.512997 & 0.512923 & 0.512912 & 0.512880 & & & \\
\hline & & 19.409 & & & 18.680 & & & \\
\hline & & 15.604 & & & 15.537 & & & \\
\hline & & 38.773 & & & 38.349 & & & \\
\hline & 6.08 & 5.84 & 5.41 & 5.78 & 6.36 & & & \\
\hline
\end{tabular}

by LILE-rich "fluids" released during dehydration of subducted oceanic crust. However, it is difficult to see how such large-scale processes could selectively enrich the sources of only a few magma batches without similarly affecting very large volumes of the mantle wedge.

\section{Isotopic Compositions}

$\mathrm{Sr}, \mathrm{Nd}, \mathrm{Pb}$, and $\mathrm{O}$ isotopic compositions have been measured for selected samples to further constrain the source characteristics of SWC basalts. These data are briefly summarized here and will be evaluated in detail in papers in preparation. The observed ranges in $8^{18} \mathrm{O}\left(5.4-7.7 \%\right.$ ) ${ }^{87} \mathrm{Sr} /$ ${ }^{80} \mathrm{Sr}(0.7028-0.7040),{ }^{143} \mathrm{Nd} /{ }^{144} \mathrm{Nd}(0.51284-0.51304),{ }^{206} \mathrm{~Pb} /$ ${ }^{204} \mathrm{~Pb}(18.68-19.40),{ }^{207} \mathrm{~Pb} /{ }^{204} \mathrm{~Pb}(15.53-15.66)$, and ${ }^{208} \mathrm{~Pb} /$ ${ }^{204} \mathrm{~Pb}(38.4-39.2)$ are significant, and these ratios display important correlations with other geochemical data. Isotopic ranges for other Cascade volcanoes are comparable [cf. Peterman et al., 1970; Church and Tilton, 1973; Church, 1976; Leeman, 1982; Grove et al., 1982, 1988; Bacon, 1989]. For comparison, analyses of Eocene terrigenous sediments from the Oregon Coast Range (representative of likely subducted materials or possibly sedimentary sequences in the subarc crust) have present-day isotopic ratios as follows [Peterman et al., 1967, 1981; Heller et al., 1985; W. P. Leeman, unpublished data, 1989]: $\delta^{18} \mathrm{O}(\sim 10 \%),{ }^{87} \mathrm{Sr} /{ }^{86} \mathrm{Sr}$ $(0.706-0.711),{ }^{143} \mathrm{Nd} /{ }^{144} \mathrm{Nd}(0.5122-0.5124)$; the range in $\mathrm{Pb}$ isotopic composition of these sediments is shown in later figures [cf. Church, 1976].

The SWC data are portrayed as a function of silica content in Figure 8 to illustrate how they vary with bulk composition. Oxygen compositions of the basalts vary beyond nor- mal analytical precision, but much of the observed range (5.4-6.4\%) corresponds to whole rock analyses for the older SIM lavas. Further analyses of SIM feldspar separates will be carried out in the future to see if the whole rock data are reliable. Data for IH and MSH whole rock and plagioclase samples are more restricted, averaging about $5.8 \%$, whereas $\delta^{18} \mathrm{O}$ progressively increases for more silicic MSH (whole rock or pumice clast) samples. Because plagioclase separates from MSH dacite pumices have $\delta^{18} \mathrm{O}$ between 6.5 and 6.7\% (W. Hildreth, unpublished data, 1989), either the whole rock trends may result from secondary alteration (e.g., hydration) or else the plagioclases may be out of isotopic equilibrium with their host magma. We tentatively favor the latter possibility because $\delta^{18} \mathrm{O}$ in these rocks is strongly correlated with radiogenic isotope ratios and major and trace element contents. We believe that such correlations would be unlikely if $\delta^{18} \mathrm{O}$ values were seriously modified by alteration processes; this is indicated by one of the older MSH dacites analyzed by Halliday et al. [1983], which is deleted from the figures in this paper because its $\delta^{18} \mathrm{O}$ is extremely low $(\sim 4 \%)$. Furthermore, plagioclases from the May 18, 1980, eruption display abundant textural evidence for multiple episodes of resorption and reaction with the host magma [Pearce et al., 1987], and there are documented examples of phenocryst-matrix isotopic disequilibria elsewhere in the Cascades [Mazzone and Grant, 1988]. As indicated in Figure $8 b$, the rate of increase in $\delta^{18} \mathrm{O}$ in MSH rocks exceeds that predicted for fractionation of observed phenocrysts.

Radiogenic isotopic ratios do not vary consistently between the basalts and the more evolved lavas. The basalts 

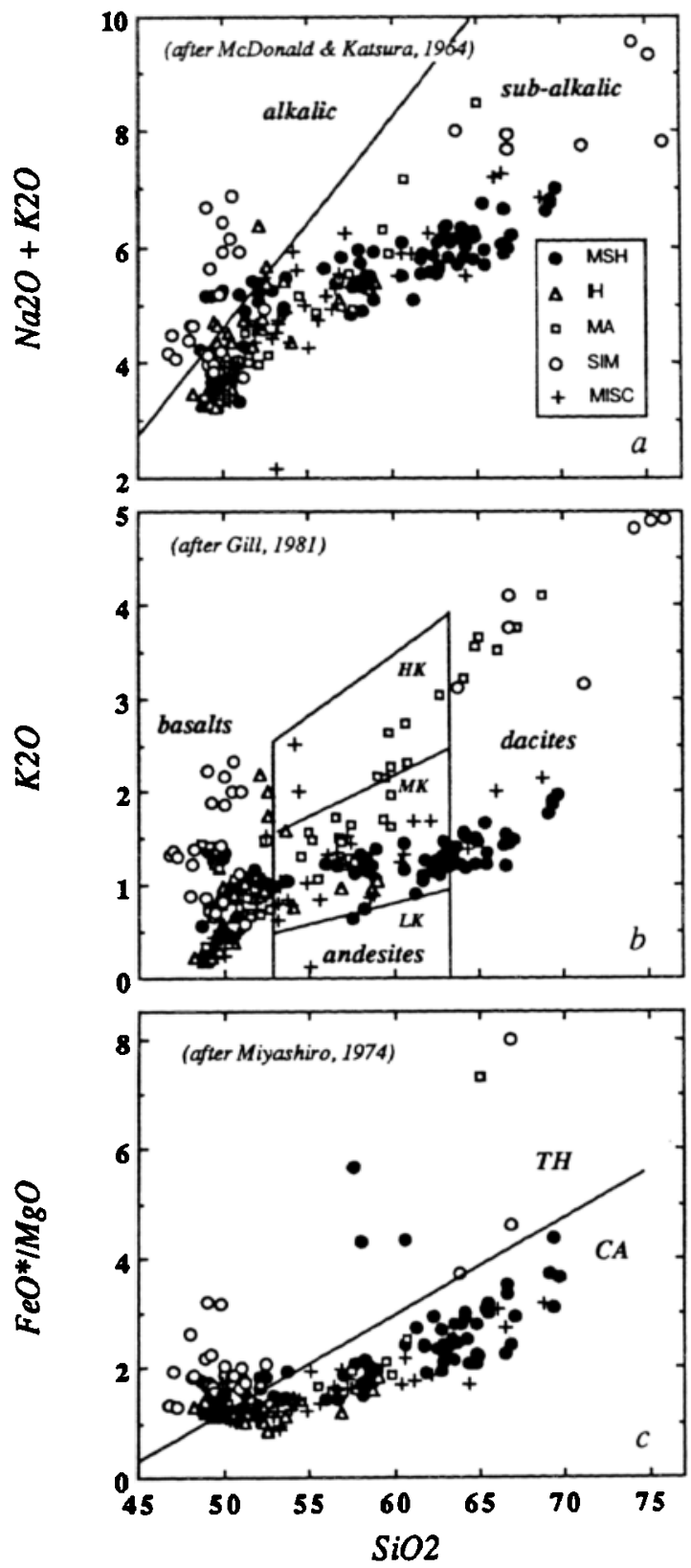

Fig. 2. Variation diagrams showing (a) total alkalies, (b) $\mathrm{K}_{2} \mathrm{O}$, and $(c) \mathrm{FeO}^{*} / \mathrm{MgO}$ versus $\mathrm{SiO}_{2}$. Classification criteria are discussed by Gill [1981]. This plot compares samples from the four major volcanic complexes (MSH, IH, MA, and SIM) and from miscellaneous minor vents shown by letters in Figure 1. A few silicic lavas with very high $\mathrm{FeO}^{*} / \mathrm{MgO}$ plot off the field of view.

cover nearly the entire range in $\mathrm{Sr}, \mathrm{Nd}$, and $\mathrm{Pb}$ isotopic compositions but show no significant correlations between silica and these ratios. Isotopic variations in the evolved lavas are more systematic, but differ between volcanoes. In MSH lavas, $\mathrm{SiO}_{2}$ is positively correlated with ${ }^{87} \mathrm{Sr} /{ }^{86} \mathrm{Sr}$ and negatively correlated with ${ }^{143} \mathrm{Nd} /{ }^{144} \mathrm{Nd}$; a weak negative correlation exists between $\mathrm{SiO}_{2}$ and the $\mathrm{Pb}$ isotopic ratios. In MA lavas $\mathrm{SiO}_{2}$ is poorly (negatively?) correlated with all these ratios. It is evident that open system processes must have operated to produce evolved SWC magmas and that petrogeneses of the basaltic and more evolved magmas at

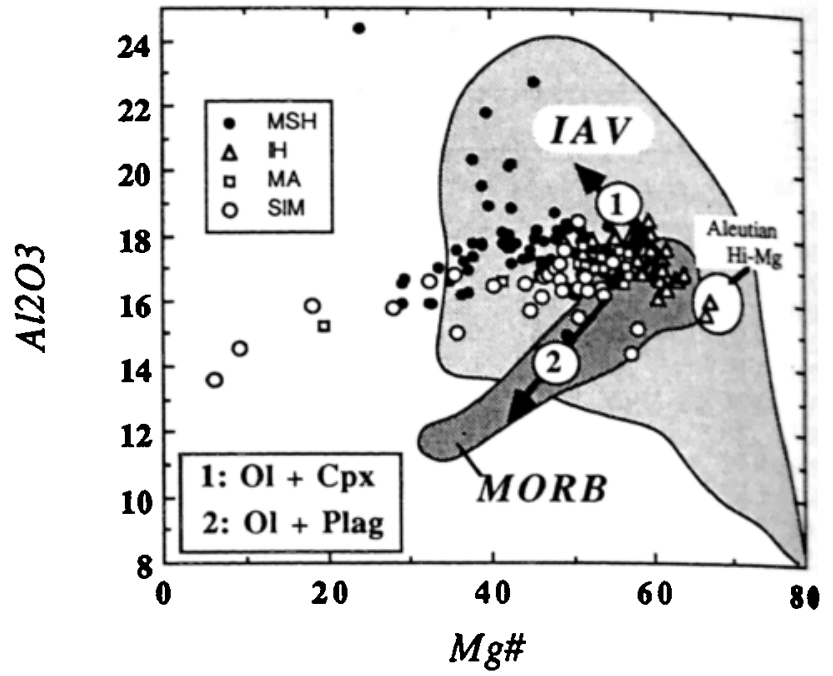

Fig. 3. $\mathrm{Al}_{2} \mathrm{O}_{3}-\mathrm{Mg}$ \# diagram showing Cascades lavas relative to fields for mid-ocean ridge basalts (MORB), island arc volcanic rocks (IAV), and Aleutian high-magnesian basalts [after Gust and Perfi. 1987]. Vectors are shown corresponding to approximate compositional variations resulting from removal of olivine and either cljnopyroxene (1, high pressure) or plagioclase (2. low pressure). All MSH samples with $\mathrm{Mg}$ \# near or below 40 and high $\mathrm{Al}_{2} \mathrm{O}_{3}(>19 \%)$ are dacitic whole pumice clasts from early eruptive periods.

each volcanic center are not identical, or perhaps even linked.

Figure 9 shows isotopic compositions plotted versus $\mathrm{Ba} / \mathrm{Nb}$ to emphasize the distinctions in trace element variations noted earlier. For the basaltic rocks, there is little correlation between $\mathrm{Ba} / \mathrm{Nb}, \delta^{18} \mathrm{O}$, or $\mathrm{Pb}$ isotopic ratios, although ${ }^{87} \mathrm{Sr} /{ }^{86} \mathrm{Sr}$ correlates positively with $\mathrm{Ba} / \mathrm{Nb}$ (also $\mathrm{Ba} / \mathrm{Zr}$, not shown). However, this trend belies considerable complexity when it is recalled that $\mathrm{Ba} / \mathrm{Nb}$ exhibits opposite correlations with silica in MSH (t) and MA (-) evolved lavas. The high $\mathrm{Ba} / \mathrm{Nb}$ IH basalts have ${ }^{87} \mathrm{Sr} /{ }^{86} \mathrm{Sr}$ ratios similar to those in the more evolved SWC lavas but retain relatively high ${ }^{143} \mathrm{Nd} /{ }^{144} \mathrm{Nd}$. However, it appears that LILE HFSE fractionation (i.e., $\mathrm{Ba}, \mathrm{Sr}$ enrichment) and elevated ${ }^{87} \mathrm{Sr} /{ }^{86} \mathrm{Sr}$ in these basaltic magmas result from different processes than those involved in production of SWC intermediate and silicic magmas. For example, the basalts differ in that they display positive correlation between $\mathrm{Sr}$ content and ${ }^{87} \mathrm{Sr} /{ }^{86} \mathrm{Sr}$, and $\mathrm{Sr}$ contents correlate positively with abundances of the incompatible trace elements (e.g., $\mathrm{Nb}$. $\mathrm{La}, \mathrm{Ba}, \mathrm{Th})$. These features suggest that elevation of ${ }^{87} \mathrm{Sr} /$ ${ }^{86} \mathrm{Sr}$ occurred at pressures above the stability of plagioclase such that $\mathrm{Sr}$ behaved as an incompatible element (e.g. subcrustal depths [cf. Leeman and Hawkesworth, 1986]).

Isotope-isotope correlations provide additional constraints. Sr-Nd variations in SWC volcanic rocks (Figure 10) mimic the fields of oceanic basalts, with more evolved rocks apparently displaced to the right of the "mantle array" and with ${ }^{143} \mathrm{Nd} /{ }^{144} \mathrm{Nd}$ shifted slightly to lower values than in the basalts. The high $\mathrm{Ba} / \mathrm{Nb}$ lavas are distinct from other $\mathrm{IH}$ basalts in that they display increasing ${ }^{87} \mathrm{Sr} /{ }^{86} \mathrm{Sr}$ with only slight decrease in ${ }^{143} \mathrm{Nd} /{ }^{144} \mathrm{Nd}$. SIM basalts define a distinct trend slightly below the "mantle array," whereas MSH evolved lavas trend slightly to the right of the array. $\mathrm{Pb}$ isotope data define distinctive positive correlations between ${ }^{206} \mathrm{~Pb} /{ }^{204} \mathrm{~Pb}$ and both ${ }^{207} \mathrm{~Pb} /{ }^{204} \mathrm{~Pb}$ and ${ }^{208} \mathrm{~Pb} /{ }^{204} \mathrm{~Pb}$ (Figure II) 

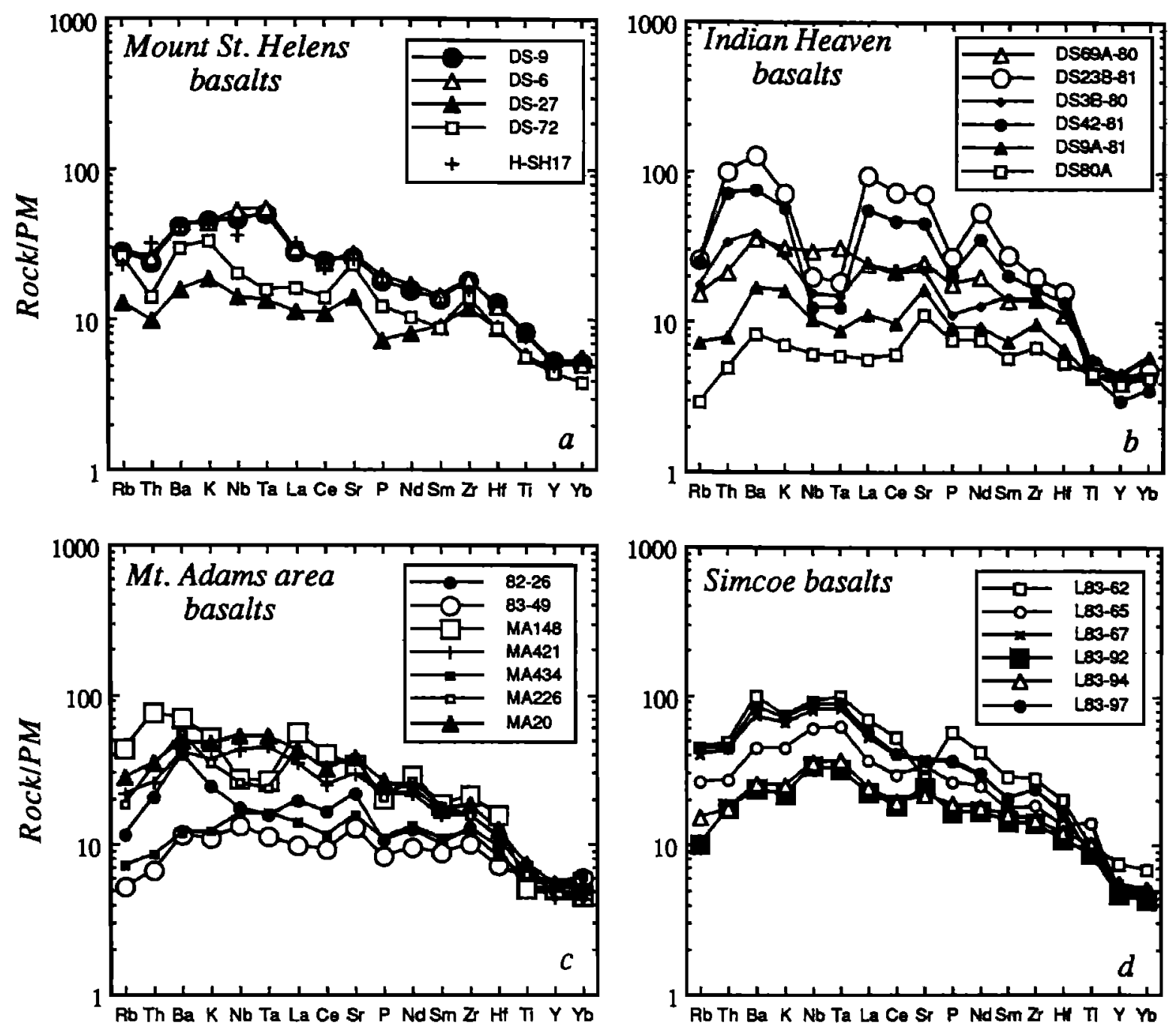

Fig. 4. "Incompatible" trace element abundances in selected SWC basalts (all $<53 \% \mathrm{SiO}_{2}$ ) as normalized to Wood's [1979] estimated primitive mantle composition (model MORB source). Representative samples showing the range in basalt compositions are shown for each major volcano as follows: (a) MSH, (b) IH, (c) MA, and (d) SIM. Line profiles are omitted for MA samples because analytical data are less complete and $\mathrm{La}, \mathrm{Ce}$, and $\mathrm{Nd}$ were measured by relatively imprecise XRF methods. Note that few SWC basalts display relative depletions of HFSE (e.g., Nb, Ta) which are characteristic of volcanic arc magmas. Only a few samples from IH (also from some of the miscellaneous vents, not shown) display these features; these samples also exhibit relative depletions of $\mathrm{P}_{2} \mathrm{O}_{5}$. Profiles for the other three volcanoes are much more internally similar.

and lie between fields for oceanic basalts (represented by Pacific MORB [White et al., 1987] and the northern hemisphere regression line (NHRL [Hart, 1984]) for oceanic basalts) and that for NE Pacific sediments, many of which have a large component of terrigenous detritus [Church, 1976]. Compositions of Cascade ore leads [Church et al., 1986] overlap with the most radiogenic lavas. Average Juan de Fuca Ridge basalt is indicated for reference [Hegner and Tatsumoto, 1987], along with the model crustal $\mathrm{Pb}$ isotope growth curve of Stacey and Kramers [1975]. The trend of the Cascade array suggests that the arc magmas might contain a component of $\mathrm{Pb}$ similar to that in the sediments or the crust, as was suggested by Church and Tilton [1973] and Church [1976]. However, the new results show that basaltic magmas contain more radiogenic $\mathrm{Pb}$ than in the associated silicic magmas. One possible explanation for this trend is that owing to their low $\mathrm{Pb}$ contents and higher temperatures, the basaltic magmas may be more susceptible to effects of crustal contamination. Analytical uncertainties in the available XRF $\mathrm{Pb}$ analyses prectude detailed discussion of the systematics. Production of the high ${ }^{207} \mathrm{~Pb} /{ }^{204} \mathrm{~Pb}$ basalts via contamination is possible if average crust resembles the ore lead data but is unlikely if Pb compositions of MSH silicic magmas (Figure 11 [also cf. Halliday et al., 1983]) are more representative of possible crustal contaminants (cf. Figure 8a).

Alternatively, radiogenic $\mathrm{Pb}$ signatures in SWC basalts could be attributed to inheritance from subduction-modified mantle source regions [cf. Morris and Hart, 1983; Hickey et al., 1986]. For several reasons this possibility is considered implausible. Figure 12 shows little or no correlation between $\mathrm{Sr}$ and $\mathrm{O}$ isotopic compositions of SWC basalts, whereas there is a weak negative correlation between $\mathrm{Pb}$ and $\mathrm{O}$ compositions. Although oxygen isotopic data are not as 


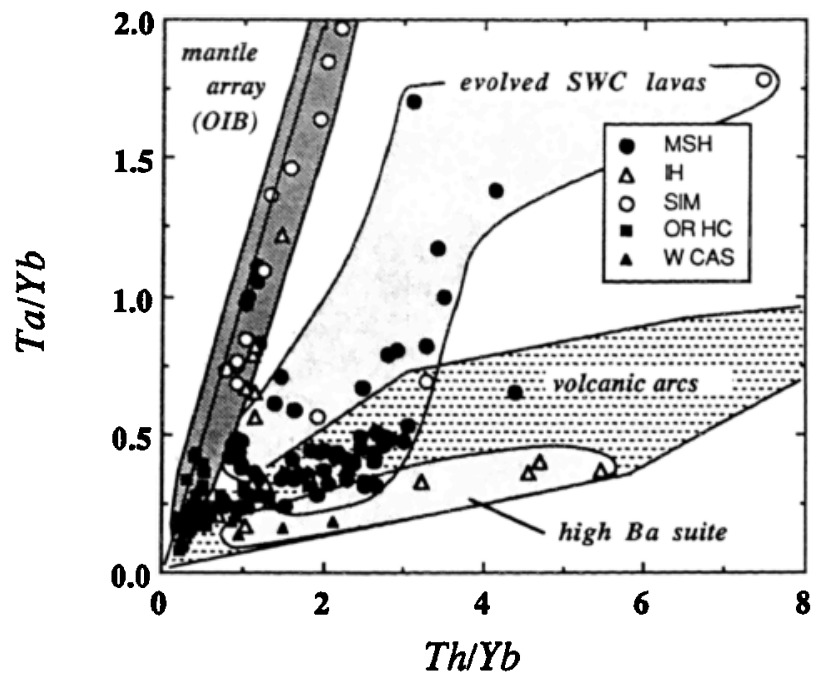

Fig. 5. $\mathrm{Th} / \mathrm{Yb}-\mathrm{Ta} / \mathrm{Yb}$ diagram showing SWC lavas; a few basalts from the Oligocene-Pliocene Western Cascades (W CAS (W. P. Leeman, unpublished data, 1990)) and Pleistocene central High Cascades (OR HC [Hughes and Taylor, 1986]) of Oregon are shown for comparison along with the field for typical volcanic arc magmas [Pearce, 1983]. Distinct stippled fields are shown for HFSEdepleted (low Ta/Yb) basalts from the IH field and a "mantle array" defined by most other SWC basalts, and by typical oceanic island basalts (OIB). Samples plotting between these two fields are evolved lavas $\left(>53 \% \mathrm{SiO}_{2}\right)$.

sensitive as $\mathrm{Pb}$ isotopes to this form of source contamination, the observed $\mathrm{Pb}-\mathrm{O}$ isotopic trend (unlikely to be an artifact of analytical uncertainty) is inconsistent with involvement of significant quantities of marine sediments which typically have high $\delta^{18} \mathrm{O}$ [e.g., Heller et al., 1985]. Furthermore, in the SWC lavas as a whole, there are weakly negative correlations between ${ }^{207} \mathrm{~Pb} /{ }^{204} \mathrm{~Pb}$ and a variety of other compositional features that typify sediments (e.g., high $\mathrm{Ba} / \mathrm{Zr}, \mathrm{Rb} / \mathrm{Zr}, \mathrm{K} / \mathrm{Zr}, \mathrm{Ba} / \mathrm{Nb}, \mathrm{Ba} / \mathrm{La}, \mathrm{SiO}_{2}$, and ${ }^{87} \mathrm{Sr} /{ }^{86} \mathrm{Sr}$ ); these correlations (not shown) seemingly preclude sediment contamination of either the mafic magmas or their mantle source as explanations for the high ${ }^{207} \mathrm{~Pb} /{ }^{204} \mathrm{~Pb}$ ratios. Finally, the high ${ }^{207} \mathrm{~Pb} /{ }^{204} \mathrm{~Pb}$ ratios could be inherited from old subcontinental lithospheric mantle, but there is no geologic evidence to support the existence of such a reservoir near the SWC transect. $\mathrm{Pb}, \mathrm{Sr}$, and $\mathrm{O}$ compositions of $\mathrm{MSH}$ intermediate and silicic rocks are correlated and suggest that these magmas contained a significant crustal component in concert with their proposed crustal anatectic origin [Smith and Leeman, 1987]. The SIM basalts are notable because, rather than follow the trend of other Cascades data in Figure 11 , analyses of these rocks approximate the NHRL line. Thus there is little reason to suspect that these magmas contain much of a subducted slab component.

Another line of reasoning against significant contribution of subducted sediment to SWC magmas involves the geochemistry of boron. Strong correlation of B with ${ }^{10} \mathrm{Be}$ concentrations in arc magmas [Morris et al., 1990] provides compelling evidence that the observed $B$ enrichments are related to subduction processes. Leeman [1987] demonstrated that magmas from nearly all volcanic arcs are systematically enriched in $B$ relative to within-plate magmas, and that OIB lavas have low $\mathrm{B} / \mathrm{Nb}$ ratios $(<0.1)$, whereas arc magmas have much higher ratios $(>0.5$, commonly between
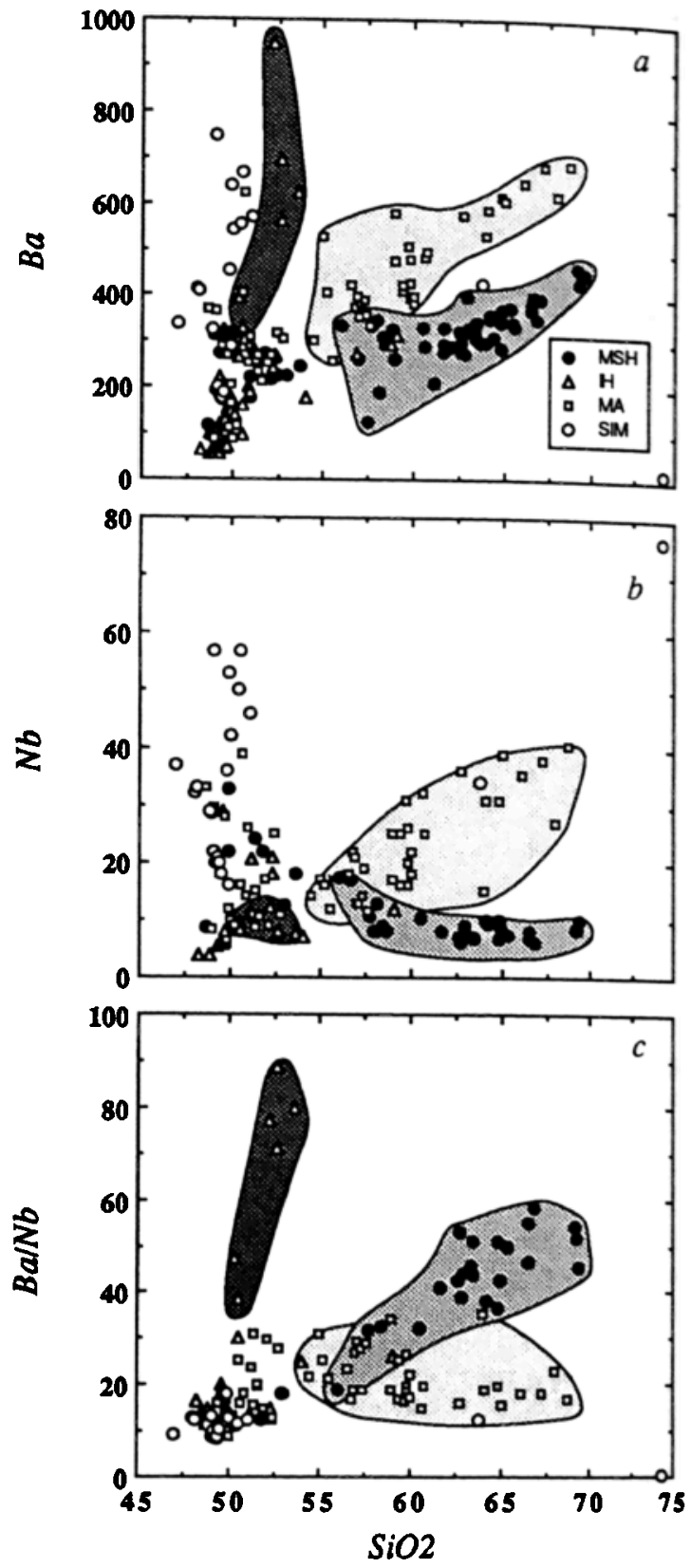

Fig. 6. Variations in (a) $\mathrm{Ba},(b) \mathrm{Nb}$, and (c) $\mathrm{Ba} / \mathrm{Nb}$ versus $\mathrm{SiO}_{2}$. Basaltic lavas define virtually the entire range in $\mathrm{Ba}$ and $\mathrm{Nb}$ concentrations. Most of these rocks have low $\mathrm{Ba} / \mathrm{Nb}(<20)$, typical of OIB; those with higher $\mathrm{Ba} / \mathrm{Nb}$ are HFSE-depleted IH basalts (dark stippled field). Evolved lavas from MA (light stippling) show $\mathrm{Ba}$ and $\mathrm{Nb}$ enrichments and slight $\mathrm{Ba} / \mathrm{Nb}$ decrease with increasing $\mathrm{SiO}_{2}$, consistent with dominantly fractional crystallization differentiation. Those from MSH (medium stippling) display compositional variations inconsistent with simple crystal fractionation (see text).

1 and 20). Figure 13 compares $\mathrm{B} / \mathrm{Nb}$ ratios with other parameters. All SWC basalts contain less than $5 \mathrm{ppm} \mathrm{B}$, and average $\sim 2 \mathrm{ppm}$, essentially overlapping with OIB values. Those which conform to the mantle arrays discussed eartier have high $\mathrm{Ta} / \mathrm{Sm}(0.25-0.5)$ and low $\mathrm{B} / \mathrm{Nb}$ ratios $(<0.2)$ similar to those in OIB. The distinctive HFSE-depleted IH basalts display higher $\mathrm{B} / \mathrm{Nb}$ (up to 0.5 ) and radiogenic $\mathrm{Sr}$, as well as enrichments in $\mathrm{Sr}, \mathrm{Ba}$, and other incompatible elements. Even andesitic SWC lavas have B/Nb below 0.5. In contrast, MSH dacites have high $B$ (up to $24 \mathrm{ppm}$ ) and 

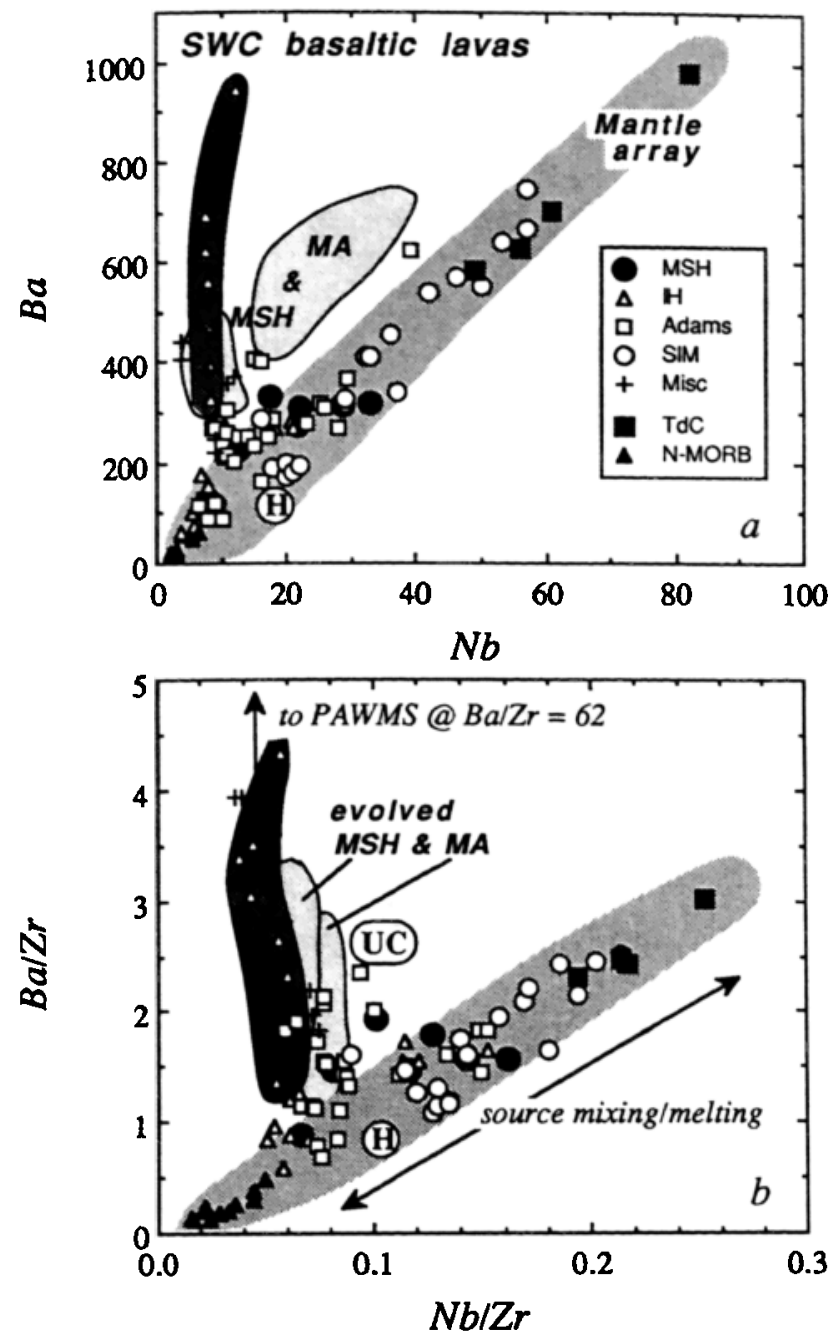

Fig. 7. (a) $\mathrm{Ba}$ versus $\mathrm{Nb}$ and (b) $\mathrm{Ba} / \mathrm{Zr}$ versus $\mathrm{Nb} / \mathrm{Zr}$ in $\mathrm{SWC}$ basaltic lavas $\left(<53 \% \mathrm{SiO}_{2}\right)$. For clarity, the compositional field for evolved MA and MSH rocks is shown only by light stippling. HFSE-depleted $1 \mathrm{H}$ basalts (dark stippling) and samples from some of the miscellaneous smaller vents display $\mathrm{Ba}$ and $\mathrm{Ba} / \mathrm{Zr}$ enrichments toward approximate composition of pelagic sediments (as represented by PAWMS average of Hole et al. [1984]). Average upper crust (point UC [Taylor and McLennan, 1985]) is plotted to show that melting of, or contamination by, such material cannot explain the high $\mathrm{Ba} / \mathrm{Zr}$ and $\mathrm{Ba} / \mathrm{Nb}$ values observed. Remaining samples display coupled enrichment in $\mathrm{Ba}$ and $\mathrm{Nb}$ and define a "mantle array" trend (medium stippling) similar to that for oceanic basalts (represented by Tristan de Cunha [B. L. Weaver et al., 1987], BHVO-1 Hawaiian tholeiite (point H lcf. Govindaraju, 1984]), NMORB [Le Roex et al., 1983]; the stippled field covers the range for several hundred OIB analyses ((W. P. Leeman, unpublished data and literature compilation, 1990)). The strong linearity of this array suggests that this group of SWC basalts could be derived by melting a mixed reservoir consisting of OIB and MORB source mantle components.

$\mathrm{B} / \mathrm{Nb}(1-3)$. Thus the range in $\mathrm{B} / \mathrm{Nb}$ in these various $\mathrm{MSH}$ magmas (along with other isotopic and trace element data) is inconsistent with cogenetic relations because magmatic processes are unlikely to fractionate such highly incompatible elements. Near-linear covariation of $\mathrm{B} / \mathrm{Nb}$ and other parameters in the evolved lavas (Figure 13) more likely results from mixing between partial melts of the underlying crust thigh B, possibly derived from forearc sediments) and low-B mafic magmas. A possible implication of these results is that the mafic magmas were produced with little input from the subducted oceanic slab compared to the situation in other volcanic arcs.

\section{Discussion}

The foregoing descriptive information places a number of constraints on the nature of magma generation associated with Cascades subduction processes, but perhaps more importantly illustrates how little we really understand these processes. The modern (late Pliocene and younger) Cascades magmatism, at least in southern Washington, stands out as being unusual compared to most volcanic arcs (except as noted below). Some of the most notable features are summarized here.

Compared to many other continental margin arcs [cf. Leeman, 1983], basaltic volcanism is relatively common in the SWC. This is apparently typical of much of the Cascades arc [e.g., Hughes and Taylor, 1986; Hughes. this issue: Guffanti et al., this issue: Taylor, this issue], although true basalts are not everywhere present [cf. Luedke and Smith. 1982; Bacon et al., this issue] and more evolved lavas dominate the major stratovolcanoes. Although Basin and Range style deformation appears to have recently propagated northwestward into the southern Cascades and to the backarc region of central Oregon [cf. Wells and Heller, 1988], it seems unlikely that this development is responsible for the abundance of basaltic lavas in the Cascades. First, basaltic magmatism was volumetrically significant in central Oregon throughout the Neogene (since $\sim 40 \mathrm{Ma}$ ) when convergence rates were much higher than at present [Rea and Duncan, 1986: Verplanck and Duncan. 1987; Priest, this issue]; initiation of Basin and Range style deformation in the Great Basin postdates and could not have influenced this early Cascade volcanism. Also, as emphasized here, orientations of late Neogene structures in the SWC are inconsistent with Basin and Range style extension [cf. Zoback and Zoback, 1980]. The abundance of basalt in the central Cascades may be enhanced by additional factors such as the presence of thinner or more mafic crust relative to adjacent segments in northern California or north central Washington [McBirney, 1978], proximity to segmentation boundaries [Hughes et al., 1980; Weaver and Michaelson, 1985: Guffanti and Weaver, 1988], or development of intra-arc extension related to along-strike variations in obliquity of convergence [Rogers, 1985] or decrease in convergence rates with time [Verplanck and Duncan, 1987]. At this stage we feel it is premature to critically evaluate these possibilities, much less adopt any single explanation for high basaltic magma production in the Cascades.

Another striking anomaly concerns the prevalence in the SWC of basaltic magmas that have strong geochemical similarities to oceanic island basalts (OIB); many of those at SIM are true alkali olivine basalts (some containing sparse spinal lherzolite xenoliths). Alkali basalts also occur in back arc regions of several volcanic arcs (e.g. Japan, Argentina [cf. Gill, 1981; Sakuyama and Nesbitt, 1986; Stern et al., 1986; Munoz and Stern, 1989]), and it is tempting to draw analogies between the Cascades and back arc settings, especially concerning the SIM basalts. More rarely, such magmas occur within intra-arc extensional zones (e.g., New Hebrides, Fiji [Gill, 1981, 1984; Gill and Whelan, 1989a, b]). 

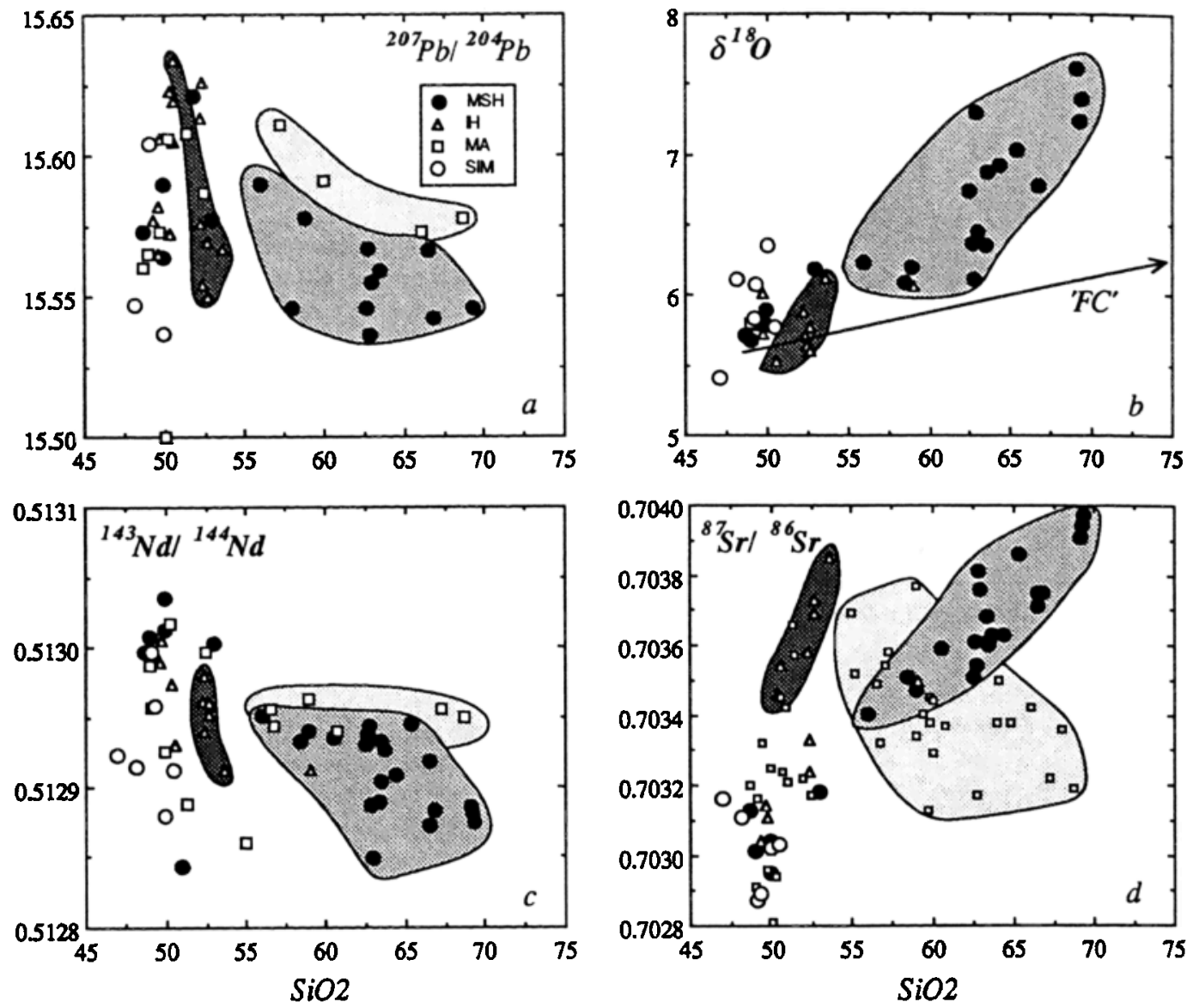

Fig. 8. (a) $\mathrm{Pb},(b) \mathrm{O}$, (c) $\mathrm{Nd}$, and (d) $\mathrm{Sr}$ isotopic compositions versus $\mathrm{SiO}_{2}$ for $\mathrm{SWC}$ volcanic rocks. Basaltic rocks define virtually the gamut of radiogenic isotopic compositions, but they are relatively uniform in $\delta^{18} \mathrm{O}$. HFSE-depleted $\mathrm{IH}$ lavas (dark stippling) display significant correlations between $\mathrm{SiO}_{2}$ and ${ }^{207} \mathrm{~Pb} /{ }^{207} \mathrm{~Pb}, \delta^{18} \mathrm{O}$, and ${ }^{87} \mathrm{Sr} /{ }^{86} \mathrm{Sr}$. Evolved lavas from MSH (medium stippling) and MA (light stippling) are distinctive (although oxygen isotopic data are not available for the MA samples); this is especially true for ${ }^{87} \mathrm{Sr} /{ }^{86} \mathrm{Sr}$ trends. Each volcano has experienced open-system evolution, but specific processes must differ in each case. A vector indicating fractional crystallization (FC) effects is shown for $\delta^{18} \mathrm{O}$ to illustrate that MSH magmas cannot be related simply by this process; they more likely represent mixtures between silicic crustal melts (i.e., the dacites) and basaltic magmas [cf. Smith and Leeman, 1987]. The low ${ }^{143} \mathrm{Nd} /{ }^{144} \mathrm{Nd}$ (also ${ }^{87} \mathrm{Sr} /{ }^{86} \mathrm{Sr}=0.7041$ ) mafic sample from $\mathrm{MSH}$ is a gabbroic xenolith from one of the dacite dome eruptions (Goat Rocks); its relation to other MSH basalts is unclear.

Both OIB-like and typical arc basalts occur in volcanoes from Central America [cf. Reagan and Gill, 1989], the western Mexican volcanic belt [Verma and Nelson, 1989; Luhr et al., 1989], southwestern Japan and nearby Korea and China [Nakamura et al., 1989], and other arcs with young subducting plates [Reagan and Gill, 1989]. Shoshonitic magmas also occur along the volcanic front in the northern seamount province of the Mariana-Volcano arc [Stern et al., 1988]. Unlike these examples, OIB-like basalts are distributed across the entire SWC traverse and are the rule rather than the exception.

Relative to OIB magmas, for example, most volcanic arc basaltic lavas are characterized by anomalous enrichments of alkali and alkaline earth metals, by depletions of HFSE, and by high LILE/HFSE (e.g., $\mathrm{Ba} / \mathrm{Nb}$ ) and high LILE light rare earth element (LREE) (e.g., Ba/La) ratios [Green, 1980; Perfit et al., 1980; Arculus and Johnson, 1981; Morris and Hart, 1983; Ito and Stern, 1985; Hickey et al., 1986; Sakuyama and Nesbitt, 1986; Tatsumi et al., 1986; Hildreth and Moorbath, 1988]. As discussed by these authors, the unique chemical characteristics of arc magmas are com- monly attributed to the influence of aqueous fluids on phase equilibria and element transport in the subduction zone environment (possibly augmented by crustal contamination of arc magmas). Specifically, most recent arc petrogenetic models propose that dominantly aqueous fluids are released from the downgoing slab of oceanic lithosphere, and that these fluids may promote melting of the slab or, following upward migration, of the mantle wedge. Under high pressure conditions the fluid phase could preferentially extract from the slab and transport soluble components (e.g., LIL trace elements) into the overlying wedge; melting of such metasomatized wedge mantle could produce arc magmas [cf. Ellam and Hawkesworth, 1988; Tatsumi, 1989]. It has also been proposed that variable water activity (for example) could stabilize phases with relatively high partition coefficients for $\mathrm{Nb}, \mathrm{Ta}$, and $\mathrm{Ti}$ within arc magma sources [Saunders et al., 1980; Arculus and Powell, 1986]; depletion of such phases with increasing extent of melting could possibly produce a range of magma types with differing degrees of $\mathrm{Nb}$ depletion. The coexistence of OIB-like (no Nb depletion) and typical are ( $\mathrm{Nb}$-depleted) basalt types at Turrialba volcano (Costa 

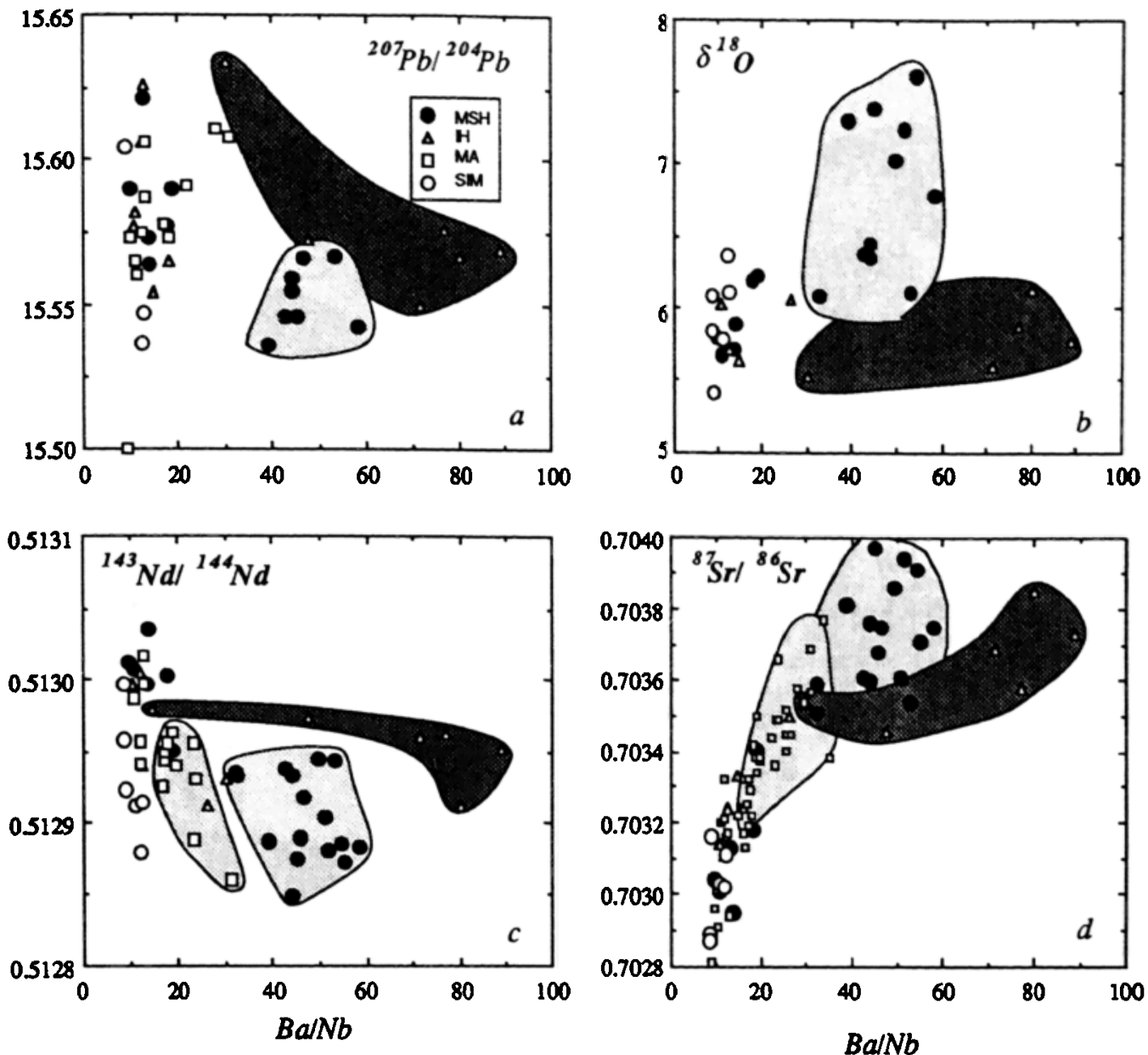

Fig. 9. Ba/ $\mathrm{Nb}$ ratio versus $(a) \mathrm{Pb},(b) \mathrm{O},(c) \mathrm{Nd}$, and $(d) \mathrm{Sr}$ isotopic compositions. Excepting the high-Ba $\mathrm{IH}$ variants (dark stippling), SWC basalts have $\mathrm{Ba} / \mathrm{Nb}<20$ and display poor correlations with all isotopic parameters except ${ }^{87} \mathrm{Sr}{ }^{86} \mathrm{Sr}$; they generally resemble typical OIB lavas [cf. Morris and Hart, 1983]. Ba/Nb in HFSE-depleted IH basalts (dark stippling) is correlated negatively with ${ }^{207} \mathrm{~Pb} /{ }^{204} \mathrm{~Pb}$ and positively with ${ }^{87} \mathrm{Sr} /{ }^{80} \mathrm{Sr}$, but these rocks are distinctive from more evolved lavas in the transect (e.g., MA and MSH andesites and dacites; light stippling). $\mathrm{Ba} / \mathrm{Nb}$ enrichment seems to have no significant correlation with $O$ isotopic compositions.

Rica) has been attributed to such a process [Reagan and Gill, 1989].

However, there are few SWC basalts with arclike HFSEdepleted compositions regardless of distance from the subduction zone. Those from the IH field are closely associated with essentially contemporaneous OIB-like variants. Basalts having similar compositional diversity to that in the SWC occur elsewhere in the Cascade arc [cf. Hughes and Taylor. 1986; Hughes, this issue; Clynne, this issue; Bullen and Clynne, this issue]. Although there seems to be a higher proportion of basalts exhibiting HFSE-depletion toward the northern [Green, 1981] and southern ends of the arc [Bruggman et al., 1987; T. Bullen and M. Clynne, personal communication, 1989], the SWC basalts that we have studied do not appear to be anomalous with respect to other contemporaneous Cascades basalts. Whether OIB-like basalts were common throughout the history of the arc, or are characteristic only of the modern Cascades is an important question that cannot be resolved without further study. Nevertheless, in recent geologic history there appears to have been a variety of basaltic sources simultaneously available within what must be a heterogeneous mantle beneath the Cascades.

\section{Implications of Basalt Diversity in the SWC}

There are perhaps two extreme viewpoints concerning the origin of basalt diversity in the Cascades. For example, the spectrum of basalt compositions may reflect varied degrees of modification (e.g., by wall rock interaction) of relatively primitive magma produced from a uniform mantle reservoir [cf. Leeman, 1983; Hildreth and Moorbath, 1988]. At the other extreme, the compositional variations may be sourcerelated and reflect partial melting of heterogeneous mantle beneath the arc, in which case the heterogeneity may result at least partly from subduction processes [e.g., Ellam and Hawkesworth, 1988; Plank and Langmuir, 1988]. To evaluate these possibilities (or an intermediate position), we consider briefly the compositional constraints provided by lavas of the SWC as well as their geologic setting.

The strong similarity to OIB and the absence of significant correlations between isotopic and trace element parameters (Figures 8, 9, and 12) in most SWC basalts appear to argue against significant crustal contamination of these magmas (with possible exception of the $\mathrm{Pb}$ isotopic data). The rarer HFSE-depleted basalts may in part reflect some form of 


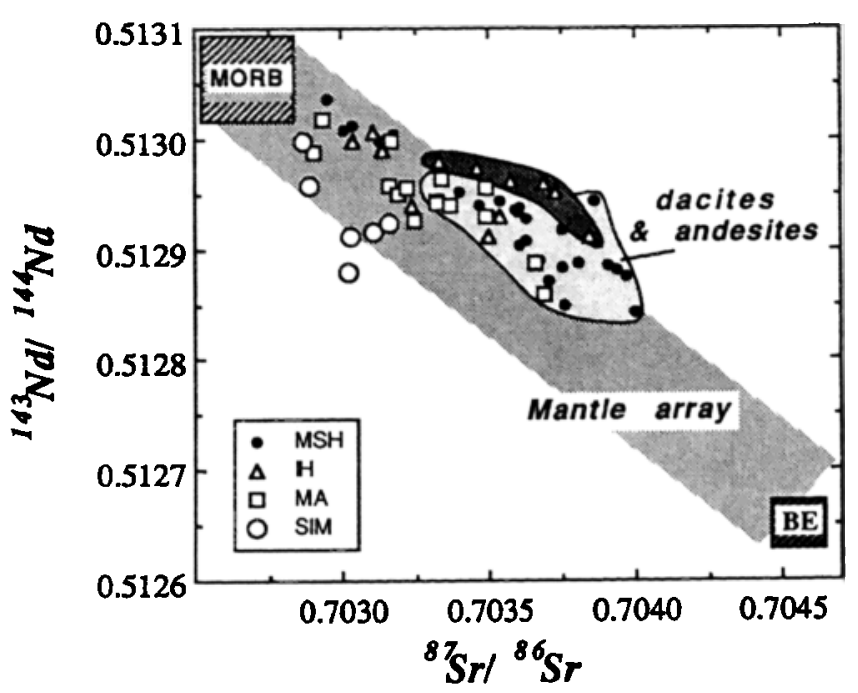

Fig. 10. Sr-Nd isotopic compositions of SWC lavas relative to typical MORB, estimated "bulk earth," and the "mantle array" defined by typical oceanic island basalts [cf. Hofmann, 1988]. Evolved rocks from MA and MSH (stippled field) are shifted toward bulk earth from the basaltic lavas, which closely resemble many OIBs.

magma contamination process because isotopic compositions $(\mathrm{O}, \mathrm{Sr}, \mathrm{Pb})$ display weak correlations with bulk compositions (Figures 8,9, and 12); trends for these basalts are usually distinct from those of more evolved lavas, indicating the need for different contaminants in each case. However, because the various SWC basalt types have overlapping $\mathrm{Mg}$ \# and transition metal abundances (cf. Table 2), it is unlikely that their differences in incompatible trace element contents can be explained solely by contamination of a common parental magma type. If $\mathrm{Nb}$ depletion with respect to $\mathrm{Ba}$ and $\mathrm{La}$ in these lavas is caused by enrichment of LIL and REE elements over $\mathrm{Nb}$, then a significantly greater proportion of subducted component is required than can be reconciled with the relatively minor shifts in isotopic composition (especially $\mathrm{Pb}$ ) and $\mathrm{B}$ concentrations associated with the required shifts in $\mathrm{Ba} / \mathrm{Nb}$. Thus we conclude that basaltic magmas in this region tapped a heterogeneous mantle source that is in part characterized by high LILE/HFSE enrichments (similar to those in normal arc magma sources) and in part consists of mantle similar to MORB and OIB source material. If the relative volumes of such components are reflected by extrusive proportions of the respective basalt variants, then the source must be dominated by the MORBand OIB-like end-members. Furthermore, $\mathrm{Nb} / \mathrm{Zr}$ ratios correlate with magma type, being lowest in the tholeitic and highest in the alkalic basalts (cf. Figure 7). Though speculative, this relationship may signify greater contribution of the MORB-like end-member to magmas produced by higher degrees of melting, and vice versa. A heterogeneous distribution of a lower melting temperature OIB source component within a more refractory matrix of MORB source material could explain such melting behavior. Such a model source is certainly consistent with the geologic and tectonic history of the Pacific Northwest margin.

The Cascade arc is a relatively young edifice built largely upon a basement of amalgamated oceanic and island arc terranes that were laterally translated and accreted to North
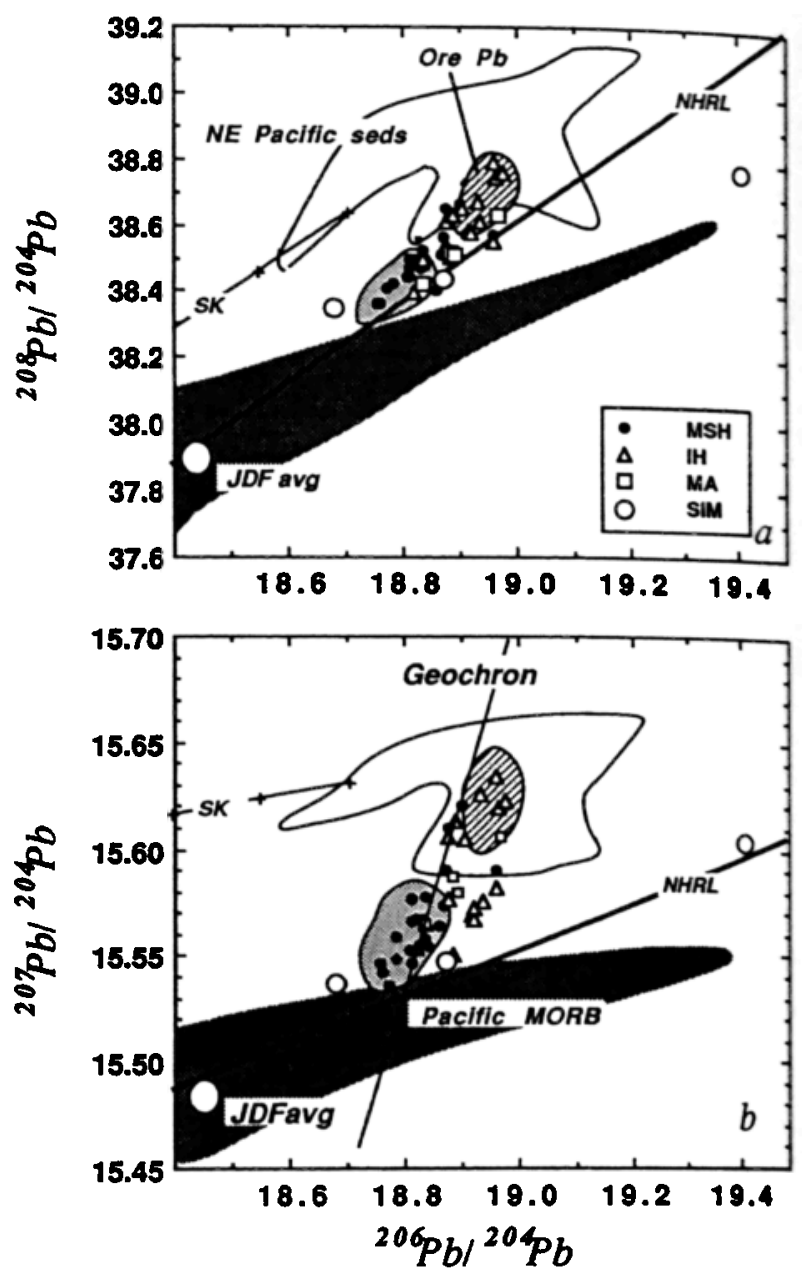

Fig. 11. (a) ${ }^{208} \mathrm{~Pb} /{ }^{204} \mathrm{~Pb}$ and $(b){ }^{207} \mathrm{~Pb} /{ }^{204} \mathrm{~Pb}$ versus ${ }^{206} \mathrm{~Pb} /{ }^{204} \mathrm{~Pb}$ diagram for SWC lavas relative to the fields of NE Pacific sediments (outlined field [Church, 1976]) and Pacific MORB (dark stipplin [White et al., 1987]). The regression line for northern hemisphere oceanic basalts (NHRL [Hart, 1984]), and an average of Juan de Fuca Ridge basalts [Hegner and Tatsumoto, 1987] also provide estimates of oceanic crust composition. The "geochron" (shown only in Figure $11 b$ ) is the locus of model single-stage $\mathrm{Pb}$ compositions, and the Stacey and Kramers, [1975] growth curve (SK) represents the time-dependent evolution of conformable $\mathrm{Pb}$ ores which approximate average crust. Actual Cascades ore leads [Church et al., 1986] plot in the cross-hatched field at the radiogenic end of the volcanic rock array. The highest ${ }^{207} \mathrm{~Pb} /{ }^{204} \mathrm{~Pb}$ samples are predominantly basalts (also see Figure $8 a$ ), whereas dacites from MSH (light stippling) plot nearer the NHRL line. SIM basalts are distinctive because they fall near NHRL (in Figure $11 b$ ) and exhibit no anomalous enrichment in ${ }^{207} \mathrm{~Pb} /{ }^{204} \mathrm{~Pb}$.

America at least by latest Cretaceous time. The basement was further modified by accretion of Paleogene oceanic fragments and forearc sediments. As pointed out by AveLallemant and Oldow [1988], oblique convergence along the Pacific margin resulted in complex jostling and transport of the pre-Cenozoic terranes. Thus underlying lithospheric mantle (to the extent that such rocks are preserved below the accreted terranes) likely includes scraps and fragments of subarc and suboceanic mantle domains, perhaps comingled by tectonic mixing. We would expect there to be heterogeneously distributed lithospheric mantle domains having both OIB and MORB source affinities. Prior to initiation of Cascades volcanism, calc-alkalic magmatism was concen- 
trated in broad belts farther to the east [cf. Oldow et al.. 1989]. The Challis volcanic belt (NE Washington and central Idaho) was active between 55 and $45 \mathrm{Ma}$, and a younger Clamo-John Day-Salmon Creek belt (east central and SE Oregon to SW Idaho) was active between about 45 and 20 Ma [Norman et al., 1986; Norman and Leeman. 1989: Hart et al.. 1989]; these volcanic belts are inferred to be related to an ancestral subduction zone located somewhere near the present Cascade axis. It has been proposed that accretion of the Coast Range block (specifically the Paleocene-Eocene oceanic island chain of Duncan [1982]) between 48 and 38 Ma led to gradual demise of this older arc and initiation of the modern Cascade subduction zone and volcanic arc [Simpson and Cox, 1977: Snavely et al., 1980; Duncan and Kulm, 1989]. Timing of this event is constrained by the 43 Ma age of the youngest Coast Range volcanic rocks (Siletz River Volcanics [Duncan, 1982]), and by the 38-40 Ma ages of earliest Cascades volcanic rocks [Lux, 1982; Phillips et al., 1986; Verplanck and Duncan, 1987]. A likely consequence of a seaward jump in position of the subduction zone is that the mantle wedge under the present Cascade arc must
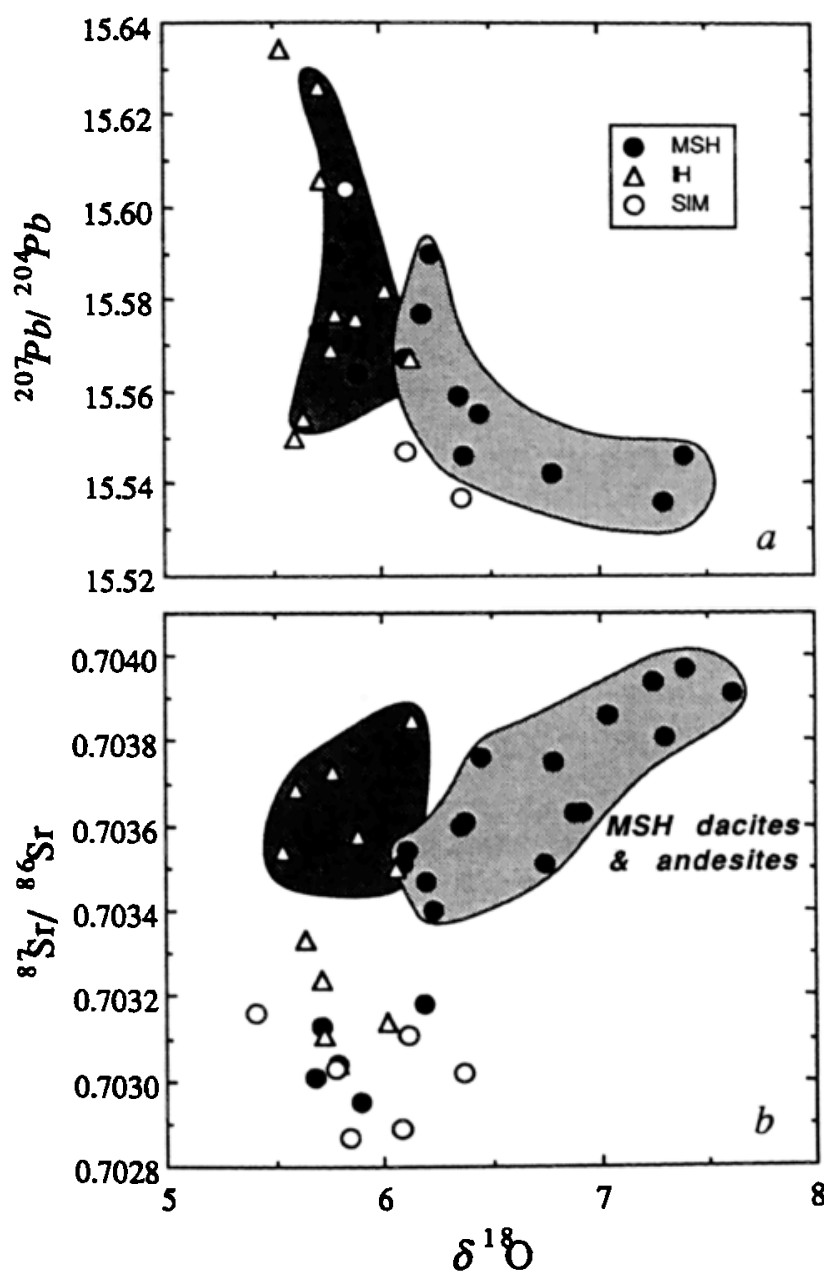

Fig. 12. The $\delta^{18} \mathrm{O}$ versus $(a){ }^{207} \mathrm{~Pb} /{ }^{204} \mathrm{~Pb}$ and $(b){ }^{87} \mathrm{Sr} /{ }^{86} \mathrm{Sr}$. MSH dacites (light stippling) and andesites (Three points with ${ }^{87} \mathrm{Sr} /{ }^{86} \mathrm{Sr}$ between 0.7034 and 0.7036 ) display significant correlations between all three isotopic parameters. The basaltic lavas (excluding HFSE-depleted IH lavas; dark stippling) display a weak negative correlation between $\mathrm{O}$ and $\mathrm{Pb}$ compositions, but neither of these correlate significantly with $\mathrm{Sr}$ composition.

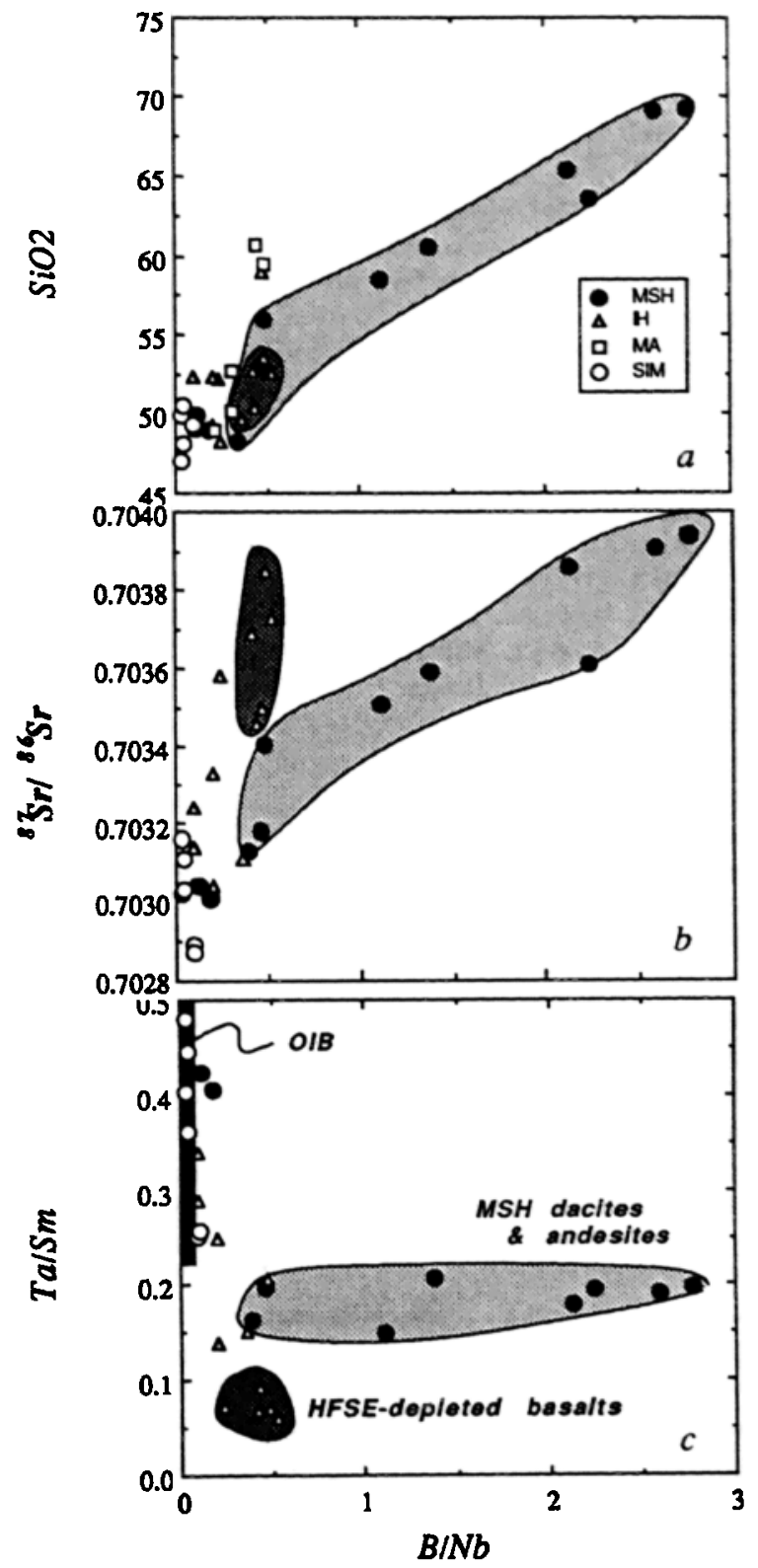

Fig. 13. (a) $\mathrm{SiO}_{2},(b){ }^{87} \mathrm{Sr} /{ }^{86} \mathrm{Sr}$, and (c) $\mathrm{Ta} / \mathrm{Sm}$ versus $\mathrm{B} / \mathrm{Nb}$ for SWC volcanic rocks. B/Nb ratios in most volcanic arc magmas exceed 0.5 , whereas OIBs are characterized by values below 0.1 [Leeman. 1987, also manuscript in preparation, 1990]; also, in arc magmas $\mathrm{B}$ correlates positively with ${ }^{10} \mathrm{Be}$, which is a robust indicator of incorporation of subducted oceanic sediments and crust [Morris et al., 1990]. The absence of B enrichment in SWC basalts suggests that they contain little subducted material. Only a few MA lavas are plotted in this figure owing to limited B analyses.

consist essentially of suboceanic (i.e., asthenospheric) mantle, and possibly a remnant of the mantle wedge (perhaps metasomatized by slab-derived fluids) formerly associated with the ancestral arcs. Thus the mantle underlying the Cascades arc may consist largely of mixed MORB and OIB source material (asthenosphere), depleted mantle (oceanic lithosphere) and remnants of metasomatized subarc mantle. This model provides a context in which the sources of modern Cascade arc magmas may be evaluated.

The paucity of typical arc basalts argues against the applicability of conventional subduction zone models involv- 
ing pervasive metasomatism of the mantle wedge by slabderived fluids. If subduction components (fluids, sediments) were added to the subarc mantle in the past (e.g., during more rapid Tertiary plate convergence), it is difficult to understand why high LILE/HFSE sources have not been tapped more frequently by young SWC magmas. We therefore conclude that the underlying mantle wedge was not metasomatized or, if so, this process only produced local heterogeneities (as in relicts of fossil subarc mantle associated with some of the accreted terranes). The apparently minor contribution of slab-derived fluids may relate to the youthfulness $(<10-20 \mathrm{Ma}$ at the trench) and warmth of the downgoing slab [Duncan and Kulm, 1989]. Using conductive thermal models, Abbott and Lyle [1984] concluded that dehydration of such a young slab would likely result in loss of volatiles $\left(\mathrm{H}_{2} \mathrm{O}\right.$ and $\left.\mathrm{CO}_{2}\right)$ well before reaching a position beneath the volcanic front (roughly $150 \mathrm{~km}$ depth [Rasmussen and Humphreys, 1988]). From petrologic considerations, Wyllie [1984, Figure 9] and Tatsumi [1989] also concluded that dehydration of hot slab would occur at relatively shallow depths, outboard of the volcanic front. Also, despite high sedimentation rates in the Cascadia Basin, the size of the accretionary prism along the NW Pacific margin indicates that a large portion of that sediment has not been subducted [Snavely et al., 1980; Duncan and Kulm, 1989]. Thus, compared to ares like the Andes, there may be a relatively small flux of subducted sediment and negligible input of dehydration fluids to metasomatize the Cascade magma sources.

However, the above view of the Cascade arc raises important questions about what triggers melting there and the extent to which aqueous fluids are necessary in producing arc magmas in general. In other words, why does the arc exist? We suggest that the Cascade arc may represent a "dry" end-member in the continuum of volcanic arcs, in which melting results from adiabatic upwelling associated with convective mantle flow (e.g., "corner flow" of Hsui et al. [1983]). Dehydration of the subducted hot slab and storage of fluids in shallow lithosphere that is not involved in magma genesis would require high temperatures (approaching the dry mantle solidus) to produce Cascades magmas. In a sense, more vigorous convention in the mantle wedge may be a consequence of subduction of hot oceanic lithosphere; in this case, mantle isotherms would not be as severely depressed as in most subduction zones, and higher temperatures would be expected below the volcanic front. Our suggestion that the source of most SWC basalts is a mixture of MORB and OIB source domains is not really new, as such components previously have been proposed on other grounds [e.g., Kay, 1978; Morris and Hart, 1983; Gill, 1981, 1984]. However, because the slab contributions so characteristic of most other arcs have been repressed, we are able to discern more clearly the effects of processes operating in the mantle wedge. We speculate that elsewhere such processes may be overprinted and even masked by slab contributions.

\section{CONCLUSIONS}

The present study documents that the geochemistry and tectonic features of the Cascade arc are unusual if not unique. Basaltic magmatism has been significant throughout the history of the arc. Particularly in the SWC sector, since
Plio-Pleistocene time voluminous basaltic magmas have been produced, including tholeiitic, calc-alkalic, and alkalic types. The role of crustal contamination in modifying Cascade basaltic magmas is considered to be small, whereas associated andesitic and dacitic magmas clearly have evolved by open system processes and contain crusta contributions. Some dacites (e.g. MSH) are interpreted crustal anatectic melts formed in response to stagnation hot basaltic magmas at or just above the crust-mantic boundary (e.g., the MASH zones of Hildreth and Moorbenh [1988]). The primitive nature of the erupted basalts and their relatively common occurrence in the SWC sector both imply that such magmas had little residence time in the crust; this view is supported by the occurrence of mantle spinel lherzolite xenoliths in some SIM basalts. The fact that the basaltic magmas either show no correlation between isotopic and trace element components or show trends quite distinct from those of the evolved lavas suggests that their compositional variability can be attributed to subcrustal processes.

The majority of basaltic samples studied are indistinguistable from oceanic island basalts (OIB) in trace element and isotopic compositions, with exception of high ${ }^{207} \mathrm{~Pb} /{ }^{204} \mathrm{~Pb}$ in some. Although similar $\mathrm{Pb}$ isotopic data are commonly attributed to some form of sediment involvement in other volcanic arcs, in the Cascades this interpretation is not supported by other observations. The absence of LILE enrichment and HFSE depletion distinguishes most SWC basalts from typical volcanic arc magmas. Because these features are generally attributed to the role of fluids released by dehydration of subducted oceanic lithosphere and to the effects of sediment subduction, we conclude that these factors are not essential in producing the SWC basalts. We infer that these basalts formed by variable degree melting of a mixed mantle source consisting mainly of heterogeneously distributed OIB and MORB source domains. Minor occurrences of HFSE-depleted (arclike) basalts in the SWC may reflect the presence of a small proportion of slabmetasomatized subarc mantle (possibly remnants of older accreted island arc terranes or of the Paleogene forearc). The juxtaposition of such different mantle domains within the lithospheric mantle is viewed as a consequence of (1) tectonic mixing associated with accretion of oceanic and island arc terranes along the Pacific margin of North America prior to Neogene time, and possibly (2) a seaward jump in the locus of subduction during the mid to late Eocene.

Finally, the Cascade arc is unusual is that the subducting oceanic plate is very young and hot. Because dehydration of this slab probably occurs outboard of the volcanic front, the role of aqueous fluids in generating arc magmas is strongly diminished compared to the situation at most convergen margins, as judged by compositions of the magmas produced. Under low fluid flux conditions, basalt generation is presumably triggered by other processes that raise the temperature of the mantle wedge to its solidus (e.g., convective mantle flow, shear heating, etc.). Although fluidenhanced melting is an attractive feature for models of subduction zone magma production, it may not be an essential one. The Quaternary Cascades provide a "dry" perspective on what is surely a wide spectrum of arc models; in this case, reduced slab contributions offer the advantage that can see in more detail the effects of processes that occur in the mantle wedge. 
Acknon'ledgments. W. P. L. thanks M. A. Menzies for his aid in aranging a sabbatical visit to the Open University where much of wis work was accomplished. C. J. Hawkesworth kindly provided ccess to the isotope facilities there, and the Open University staff provided support in many ways. We are indebted to J. G. Fitton and D. James, who provided some critical XRF analyses at the University of Edinburgh, and to Tom Bullen, who provided Nd isotopic analyses of the high $\mathrm{Ba} / \mathrm{Nb}$ IH lavas at the U.S. Geological Survey (Mento Park). M. Dehn, E. Pestana, and several students at Rice University assisted with sample preparation and ICP analyses. Oxyen isotopic data were provided by M. Matsuhisa (Geological Survey of Japan) and R. Harmon (Southern Methodist University). and J. W. Valley (University of Wisconsin) provided D. R. S. access to his laboratory for further analyses. W. H. thanks Jim O'Neil for access to his stable isotope facilities and Judy Fierstein for her ongoing support and collaboration in the study of Mount Adams. Finally, W. P. L. and D. R. S. acknowledge Paul Hammond for providing an orientation to southern Washington geology and sharing his preliminary geologic maps with us. A large portion of this research was funded by National Science Foundation support to W. P. L. (grants EAR82-14876 and EAR85-12172). Z. A. P. was supported by NERC postdoctoral fellowship. The manuscript has been improved significantly by reviews of Fred Frey, Mike Korosec, George Priest, and Mark Reagan. We also thank Pat Muffler for his role in inspiring us to prepare this paper.

\section{REFERENCES}

Abbott, D., and M. Lyle, Age of oceanic plates at subduction and volatile recycling. Geophys. Res. Lett., II, 951-954, 1984.

Anderson, J. L., Geologic map of the Klickitat 15' Quadrangle, Washington, Open File Rep. 87-14, 13 pp.. Wash. State Div. of Geol. and Earth Resour., Olympia, 1987a.

Anderson, J. L. Geologic map of the Goldendale 15' Quadrangle, Washington, Open File Rep. 87-15, 9 pp., Wash. State Div. of Geol. and Earth Resour., Olympia, $1987 b$.

Arculus, R. J., and R. W. Johnson, Island-arc magma sources: A geochemical assessment of the roles of slab-derived components and crustal contamination, Geochem. J., 15, 109-133, 1981.

Arculus, R. J., and R. Powell, Source component mixing in the regions of arc magma generation, J. Geophys. Res., 91, 59135926, 1986.

AveLallemant, H. G., and J. S. Oldow, Early Mesozoic southward migration of Cordilleran transpressional terranes, Tectonics, 7 , 1057-1075, 1988.

Bacon. C. R., Implications of silicic vent patterns for the presence of large crustal magma chambers, J. Geophys. Res., 90, 11,243$11,252,1985$.

Bacon, C. R., M. A. Lanphere, and J. R. O'Neil, Strontium and oxygen isotopes in volcanic rocks near Crater Lake, Oregon, and their bearing on arc magmatism. Geological, Geophysical, and Tectonic Setting of the Cascade Range, edited by L. J.. P. Muffier, C. S. Weaver, and D. D. Blackwell, U.S. Geol. Surv, Open File Rep., 89-178, 521-555, 1989.

Blackwell, D. D., R. G. Bowen, D. A. Hull, J. F. Riccio, and J. L. Steele, Heat flow, anc volcanism, and subduction in northern Oregon, J. Geophys. Res., 87, 8735-8754, 1982.

Briqueu, L., H. Bougault, and J. L. Joron, Quantification of Nb, Ta, $T i$, and $V$ anomalies in magmas associated with subduction zones: petrogenic implications, Earth Planet Sci. Lett., 68, 297-308, 1984.

Bruggman, P. E., C. R. Bacon, P. J. Aruscavage, R. W. Lerner L. J. Schwartz, and K. C. Stewart, Chemical analyses of rocks and glass separates from Crater Lake National Park and vicinity Oregon, U.S. Geol. Surv. Open File Rep., 87-56, 36 pp., 1987.

Bullen. T. D., and M. A. Clynne, Trace element and isotopic constraints on magmatic evolution at Lassen voleanic center, $J$. Geophys. Res., this issue.

Campbell, N, P., and R. D. Bentley, Late Quaternary deformation of the Toppenish Ridge uplift in south central Washington, Geology, 9, 519-524, 1981

Church, S. E., The Cascade Mountains revisited: A re-evaluation in light of new lead isotopic data, Earth Planet Sci. Lett., 29 , 175-188, 1976.

Cburch, S. E., and G. W. Tilton, Lead and strontium isotopic sluties in the Cascade Mountains: Bearing on andesite genesis, Geol. Sor. Am. Bull., 84, 431-454, 1973.
Church, S. E., A. P. LeHuray, A. R. Grant, M. H. Delevaux, and J. E. Gray, Lead-isotopic data from sulfide minerals from the Cascade Range, Oregon and Washington, Geochim. Cosmochim. Acta, 50, 317-328, 1986.

Clynne, M. A., Stratigraphic, lithologic, and major element geochemical constraints on magmatic evolution at Lassen volcanic center, California. J. Geophys. Res., this issue.

Duncan, R. A.. A captured island chain in the Coast Range of Oregon and Washington, J. Geophys. Res., 87, 10,827-10,837, 1982.

Duncan, R. A., and L. D. Kulm, Plate tectonic evolution of the Cascade arc-subduction complex, in The Geology of North America, vol. N, The Eastern Pacific Ocean and Hawaii, edited by E. L. Winterer, D. M. Hussong, and R. W. Decker, pp. 413-438. Geological Society of America, Boulder, Colo., 1989.

Ellam, R. M., and C. J. Hawkesworth, Elemental and isotopic variations in subduction related basalts: Evidence for a three component model, Contrib. Mineral. Petrol., 98, 72-80, 1988.

Evarts, R. C., R. P. Ashley, and J. G. Smith, Geology of the Mount St. Helens area: Record of discontinuous volcanic and plutonic activity in the Cascade arc of southern Washington, J. Geophys. Res., 92, 10,155-10,169 1987.

Farooqui, S. M.. J. D. Beaulieu. R. C. Bunker, D. E. Stensland, and R. E. Thoms, Dalles Group: Neogene formations overlying the Columbia River Basalt Group in north-central Oregon, Ore. Geol., 43, 131-140, 1981.

Gill, J., and P. Whelan, Early rifting of an oceanic island arc (Fiji) produced shoshonitic to tholeiitic basalts, J. Geophys. Res., 94, $4561-4578,1989 a$.

Gill, J., and P. Whelan, Postsubduction ocean island alkali basalts in Fiji, J. Geophys. Res., 94, 4579-4588, $1989 b$.

Gill, J. B., Orogenic Andesites and Plate Tectonics, $390 \mathrm{pp}$. Springer-Verlag, New York, 1981.

Gill, J. B., Sr-Pb-Nd isotopic evidence that both MORB and OIB sources contribute to oceanic island are magmas in Fiji, Earth Planet. Sci. Lett., 68, 443-458, 1984.

Govindaraju, K., Compilation of working values and sample description for 170 intemational reference samples of mainly silicate rocks and minerals, Geostand. Newsl., special issue, 8, 3-16, 1984

Green, N. L. Geology and petrology of Quatemary volcanic rocks, Garibaldi Lake area, southwestern British Columbia: Summary, Geol. Soc. Am. Bull., 92, 697-702, 1981.

Green, T. H., Island arc and continent-building magmatism-A review of petrogenetic models based on experimental petrology and geochemistry, Tectonophysics, 63, 367-385, 1980.

Grove, T. L. D. C. Gerlach, and T. W. Sando, Origin of calc-alkalic series lavas at Medicine Lake volcano by fractionation, assimilation and mixing, Contrib. Mineral. Petrol, 80, 160-182, 1982.

Grove, T. L., R. J. Kinzler, M. B. Baker. J. M. Donnelly-Nolan, and C. E. Lesher, Assimilation of granite by basaltic magma at Burnt lava flow, Medicine Lake volcano, northern California: Decoupling of heat and mass transfer, Contrib. Mineral. Petrol., $99,320-343,1988$

Guffanti, M., and C. S. Weaver, Distribution of late Cenozoic volcanic vents in the Cascade Range: Volcanic arc segmentation and regional tectonic considerations, J. Geophys. Res., 93, 65136529, 1988.

Guffanti, M., M. A. Clynne, J. G. Smith, L. J. P. Muffler, and T. D. Bullen, Late Cenozoic volcanism, subduction, and extension in the Lassen region of California, southem Cascade Range. $J$. Geophys. Res., this issue.

Gust, D. A., and M. R. Perfit, Phase relations of a high-Mg basalt from the Aleutian Island Arc: implications for primary island arc basalts and high-Al basalts, Contrib. Mineral. Petrol., 97, 7-18, 1987.

Halliday, A. N., A. E. Fallick, A. P. Dickin, A. B. Mackenzie, W. E. Stephens, and W. Hildreth, The isotopic and chemical evolution of Mount St. Helens, Earth Planet. Sci. Lett., 63, 241-256, 1983

Hammond, P. E. A tectonic model for the evolution of the Cascade Range, in Pacific Coast Paleogeography Symposiam, vol. 3 , Cenozoic Paleogeography of the Western United States, edited by J. M. Armentrout, M. R. Cole, and H. J. R. Terbest, pp. 219-237, Pacific Section. Society of Economic Paleontologists and Mineralogists. Los Angeles, Calif., 1979. 
Hammond, P. E. Reconnaissance geologic map and cross sections of southern Washington Cascade Range, lat. $45^{\circ} 30^{\prime}-47^{\circ} 15^{\prime} \mathrm{N}$, long. $120^{\circ} 45^{\prime}-122^{\circ} 22.5^{\prime} \mathrm{W}$, Dep. of Earth Sci., Portland State Univ., Portland, Oreg., 1980.

Hammond, P. E., and M. A. Korosec, Geochemical analyses, age dates, and flow-volume estimates for Quaternary volcanic rocks, southern Cascades Mountains, Washington, Open File Rep. 8313, 36 pp., Wash. State Div. Geol. and Earth Resour., Olympia, 1983.

Hart, S. R., A large-scale isotopic anomaly in the southern hemispheric mantle, Nature, 309, 753-757, 1984.

Hart, W. K., M. D. Norman, R. W. Carlson, and W. P. Leeman, Andesite petrogenesis in the northwestem Basin and Range: Implications for the geochemical evolution of subcontinental mantle, Geol. Soc. Am. Abstr. Programs, 21, 91, 1989.

Hegner, E., and M. Tatsumoto, $\mathrm{Pb}, \mathrm{Sr}$, and $\mathrm{Nd}$ isotopes in basalts and sulfides from the Juan de Fuca Ridge, J. Geophys. Res., 92, $11,380-11,386,1987$.

Heller, P. L., Z. E. Peterman, J. R. O'Neil, and M. Shafiqullah, Isotopic provenance of sandstones from the Eocene Tyee Formation, Oregon Coast Range, Geol. Soc. Am. Bull., 96, 770-780, 1985.

Hickey, R. L., F. A. Frey, D. C. Gerlach, and L. Lopez-Escobar, Multiple sources for basaltic arc rocks from the Southern Volcanic Zone of the Andes $\left(34^{\circ}-41^{\circ} \mathrm{S}\right)$ : Trace element and isotopic evidence for contributions from subducted oceanic crust, mantle and continental crust, J. Geophys. Res., 91, 5963-5983, 1986.

Hildreth, W., and J. Fierstein, Mount Adams: Eruptive history of an andesite-dacite stratovolcano at the focus of a fundamentally basaltic volcanic field, U.S. Geol. Surv. Open File Rep., 85-521, 44-50, 1985.

Hildreth, W., and S. Moorbath, Crustal contributions to arc magmatism in the Andes of central Chile, Contrib. Mineral. Petrol. 98, 455-489, 1988.

Hoblitt, R. P., D. R. Crandall, and D. R. Mullineaux, Mount St. Helens eruptive behavior during the last 1500 years, Geology, 8 , 555-559, 1980.

Hofmann, A. W., Chemical differentiation of the Earth: The relationship between mantle, continental crust, and oceanic crust, Earth Planet. Sci. Lett., 90, 297-314, 1988.

Hole, M. J., A. D. Saunders, G. F. Marriner, and J. Tarney, Subduction of pelagic sediments: Implications for the origin of Ce-anomalous basalts from the Mariana Islands, J. Geol. Soc. London, 141, 453-472, 1984.

Hsui, A. T., B. D. Marsh, and M. N. Toksoz, On melting of the subducted oceanic crust: Effects of subduction induced mantle flow, Tectonophysics, 99, 207-220, 1983.

Hughes, J. M., R. E. Stoiber, and M. J. Carr, Segmentation of the Cascade volcanic chain, Geology, 8, 15-17, 1980.

Hughes, S. S., Mafic magmatism and associated tectonism of the central High Cascade Range, Oregon, J. Geophys. Res., this issue.

Hughes, S. S., and E. M. Taylor, Geochemistry, petrogenesis, and tectonic implications of central High Cascade mafic platform lavas, Geol. Soc. Am. Bull., 97, 1024-1036, 1986.

Irvine, T. N., and W. R. A. Baragar, A guide to the chemical classification of the common volcanic rocks, Can.J. Earth Sci., 8, 523-548, 1971.

Ito, E., and R. J. Stern, Oxygen and strontium isotopic investigations of subduction zone volcanism: the case of the Volcano Arc and the Marianas Island Arc, Earth Planet. Sci. Lett., 76, 312-320, 1985.

Kay, R. W., Aleutian magnesian andesites: Melts from subducted Pacific Ocean crust, J. Volcanol. Geotherm. Res., 4, 117-132, 1978.

Kay, R. W., Elemental abundances relevant to identification of magma sources, Philos. Trans. R. Soc. London Ser. A, A310, $535-547,1984$

Kim, K., S. A. Dischler, J. R. Aggson, and M. P. Hardy, The state of in-situ stresses determined by hydraulic fracturing at the Hanford Site: Richland, Washington, Rep. RHO-BW-ST-73P, 172 pp., Rockwell Hanford Oper., Richmond, Wash., 1986.

Klein, F. W., Earthquakes in Lassen Volcanic National Park, California, Bull. Seismol. Soc. Am., 69, 867-875, 1979.

Korosec, M. A., Geologic map of the Mount Adams Quadrangle,
Washington, Open File Rep. 87-5, 39 pp., Wash. State Div. Geol. and Earth Resour., Olympia, 1987a.

Korosec, M. A., Geologic map of the Hood River Quadrane. Washington and Oregon, Open File Rep. 87-6, 42 pp., Wash. Ste Div. Geol. and Earth Resour., Olympia, $1987 b$.

Leeman, W. P., Tectonic and magmatic significance of strontin isotopic variations in Cenozoic volcanic rocks from the westem United States, Geol. Soc. Am. Bull., 93, 487-503, 1982.

Leeman, W. P., The influence of crustal structure on compositice of subduction-related magmas, $J$. Volcanol. Geotherm. Res., Is, 561-588, 1983.

Leeman, W. P., Boron geochemistry of volcanic arc magmas. Evidence for recycling of subducted oceanic lithosphere, Trans. $A G U, 68,462,1987$.

Leeman, W. P., and C. J. Hawkesworth, Open magmatic systemssome isotopic and trace element constraints, J. Geophys. Res. 91, 5901-5912, 1986.

Le Roex, A. P., H. J. B. Dick, A. J. Erlank, A. M. Reid, F. A. Frey and S. R. Hart, Geochemistry, mineralogy and petrogenesis of lavas erupted along the southwest Indian Ridge between the Bouvet triple junction and 11 degrees East, J. Petrol., 24, 267318, 1983.

Luedke, R. G., and R. L. Smith, Map showing distribution, coe position, and age of late Cenozoic volcanic centers in Oregon Washington, U.S. Geol. Surv. Misc. Invest. Map, I-1091D, 192.

Luhr, J. F., J. F. Allan, I. S. E. Carmichael, S. A. Nelson, and T. Hasenaka, Primitive calc-alkaline and alkaline rock types from the western Mexican volcanic belt, J. Geophys. Res., 94, 4515$4530,1989$.

Lux, D. R., K-Ar and ${ }^{40} \mathrm{Ar}-{ }^{39} \mathrm{Ar}$ ages of mid-Tertiary volcanic rocts from the western Cascade Range, Oregon, Isochron West, 33, 27-32, 1982.

MacDonald, G. A., and T. Katsura, Chemical composition of Hawaiian lavas, J. Petrol., 5, 82-133, 1964.

Mazzone, P., and N. K. Grant, Mineralogical and isotopic evideace for phenocryst-matrix disequilibrium in the Garner Mountain andesite, Contrib. Mineral. Petrol., 99, 267-272, 1988.

McBirney, A. R., Volcanic evolution of the Cascade Range, Arom. Rev. Earth Planet. Sci., 6, 437-456, 1978.

McBimey, A. R., and C. M. White, The Cascade Province, in Andesites: Orogenic Andesites and Related Rocks, edited R. S. Thorpe, pp. 115-135, John Wiley, New York, 1982.

McKee, E. M., W. A. Duffield, and R. J. Stern, Late Miocene early Pliocene basaltic rocks and their implications for crustal structure, northeastern California and south-central Oregon. Geol. Soc Am. Bull. 94, 292-304, 1983.

Michaelson, C. A., and C. S. Weaver, Upper mantle structure from teleseismic $P$ wave arrivals in Washington and northern Oregoen. J. Geophys. Res., 91, 2077-2094, 1986.

Miyashiro, A., Volcanic rock series in island arcs and active continental margins, Am. J. Sci., 274, 321-355, 1974.

Morris, J. D., and S. R. Hart, Isotopic and incompatible element constraints on the genesis of island arc volcanics from Cold and Amak Island, Aleutians, and implications for mantle stroc ture, Geochim. Cosmochim. Acta, 47, 2015-2030, 1983.

Morris, J. D. W. P. Leeman, and F. Tera, The subduction component in island arc lavas: Constraints from $\mathrm{Be}$ isotopes and B-Be systematics, Nature, 331, 31-36, 1990.

Mullineaux, D. R., Summary of pre-1980 tephra-fall deposits erupted from Mount St. Helens, Washington state, USA, Bull. Volcanol., 48, 17-26, 1986.

Munoz, J. and C. R. Stem, Alkaline magmatism within the segmeal $38^{\circ}-39^{\circ} \mathrm{S}$ of the Plio-Quatemary volcanic belt of the souther South American continental margin, J. Geophys. Res., 94, 45454560, 1989.

Nakamura, E., I. H. Campbell, and M. T. McCulloch, Chemicel geodynamics in a back arc region around the Sea of Japen. Implications for the genesis of alkaline basalts in Japan, Kort. and China, J. Geophys. Res., 94, 4634-4654, 1989.

Nakamura $\mathrm{K}$ Volcanoes as possible indicators of tectonic stres orientation, J. Volcanol. Geotherm. Res., 2, 1-16, 1977.

Norman, M. D., and W. P. Leeman, Temporal evolution of Co zoic-Cretaceous magmatism and its relation to tectonic settine southwestern Idaho, U.S.A., Earth Planet. Sci. Lett., 94, 78-9. 1989.

Norman, M. D., K. R. McElwee, R. A. Duncan, and W. P. Lem, 
K-Ar ages of Oligocene Salmon Creek Volcanics, Owyhee Mountains. SW Idaho, Isochron West, 46, 15-19, 1986.

Oldow. J. S., A. W. Bally, H. G. AveLallemant, and W. P. Leeman, Phanerozoic evolution of the North American Cordillera (United States and Canada), in The Geology of North America: An Overview, edited by A. W. Bally and A. R. Palmer, pp. 139-232. Geological Society of America, Boulder. Colo., 1989.

Or. K. M., R. W. Tabor, and V. A. Frizell, Jr., Chemical analyses of selected Tertiary and Quaternary volcanic rocks. Cascade Range. Washington, U.S. Geol. Surv. Open File Rep., 83-I, 1-14, 1983.

Pearce, J. A., Role of subcontinental lithosphere in magma genesis at active continental margins, in Continental Basults and Mantle Xenoliths. edited by C. J. Hawkesworth and M. J. Norry, pp. 230-249, Shiva, Cambridge, Mass., 1983.

Pearce, T. H., J. K. Russell, and I. Wolfson, Laser-interference and Normarskii interference imaging of zoning profiles in plagioclase phenocrysts from the May 18, 1980, eruption of Mount St. Helens, Washington, Am. Mineral., 72, 1131-1143, 1987.

Perfit, M. R., D. A. Gust, A. E. Bence, R. J. Arculus, and S. R. Taylor, Chemical characteristics of island-arc basalts: Implications for mantle sources, Chem. Geol., 30, 227-256, 1980.

Peterman. Z. E., C. E. Hedge, R. G. Coleman, and P. D. Snaveley, $\mathrm{Jr} .{ }^{87} \mathrm{Sr} /{ }^{86} \mathrm{Sr}$ ratios in some eugeosynclinal sedimentary rocks and their bearing on the origin of granitic magma in orogenic belts, Earth Planet. Sci. Lett., 2, 433-439, 1967.

Peterman, Z. E., I. S. E. Carmichael, and A. L. Smith, $\mathrm{Sr}^{87} / \mathrm{Sr}^{86}$ ratios of Quaternary lavas of the Cascade Range, northern California, Geol. Soc. Am. Bull., 81, 311-318, 1970.

Peterman, Z. E., R. G. Coleman, and C. E. Bunker, Provenance of Eocene graywackes of the Flournoy Formation near Agness, Oregon-a geochemical approach, Geology, 9, 81-86, 1981.

Phillips, W. M., M. A. Korosec, H. W. Schasse, J. L. Anderson, and $\mathrm{R}$. A. Hagen, K-Ar ages of volcanic rocks in southwest Washington, Isochron West, 47, 18-24, 1986.

Ptant, T., and C. H. Langmuir, An evaluation of the global variations in the major element chemistry of arc basalts, Earth Planet. Sci. Lett., 90, 349-370, 1988.

Priest, G. R., Overview of the geology of the central Oregon Cascade Range, in Geology and geothermal resources of the central Oregon Cascade Range, edited by G. R. Priest, and B. F. Vogt, Spec. Pap. Oreg. Dep. Geol. Miner. Ind.., 15, 3-28, 1983.

Priest, G. R., Volcanic and tectonic evolution of the Cascade volcanic arc, $44^{\circ} 00^{\prime}$ to $44^{\circ} 52.5^{\prime} \mathrm{N}, J$. Geophys. Res., this issue.

Rasmussen, J., and E. Humphreys, Tomographic image of the Juan de Fuca plate beneath Washington and western Oregon using teleseismic $P$ wave travel times, Geophys. Res. Lett., 15, 14171420, 1988.

Rea, D. K.. and R. A. Duncan, North Pacific plate convergence: a quantitative record of the past 140 m.y., Geology, 14, 373-376, 1986.

Reagan, M. K., and J. B. Gill, Coexisting calcalkaline and highniobium basalts from Turrialba volcano, Costa Rica: Implications for residual titanates in arc magma sources. J. Geophys. Res., 94, 4619-4633, 1989.

Riddihough, R. P., Recent movements of the Juan de Fuca Plate system, J. Geophys. Res., 89, 6980-6994, 1984.

Rogers. G. C., Variation in Cascade volcanism with margin orientation, Geology, 13, 495-498, 1985.

Sakuyama, M., and R. W. Nesbitt, Geochemistry of the Quaternary volcanic rocks of the northeast Japan arc, J. Volcanol. Geotherm. Res., 29, 413-450, 1986.

Saunders, A. D., J. Tarney, and S. D. Weaver, Transverse geochemical variations across the Antarctic Peninsula: Implications for the genesis of calc-alkaline magmas, Earth Planet. Sci. Lett., 46, 344-360, 1980.

Sheppard, R. A., Geology of the Simcoe Mountains volcanic area, Washington, Geol. Map GM-3, Wash. State Div. of Mines and Geol., Olympia, 1967.

Sherrod, D. R., and J. G. Smith, Quaternary extrusion rates from the Cascade Range, northwestem United States and British Columbia, J. Geophys. Res., this issue.

Simpson, R. W., and A. V. Cox, Paleomagnetic evidence for tectonic rotation of the Oregon Coast Range, Geology, 5, 585-589, 1977.
Smith, D. R., and W. P. Leeman, Petrogenesis of Mount St. Helens dacitic magmas, J. Geophys. Re's. 92. 10.313-10.334, 1987

Smith, G. A.. Late Cenozoic structures on the Columbia Plateau: Implications for tectonics in the Pacific Northwest. Eos Trans. $A G U, 63,1116,1982$.

Smith, G. A.. L. W. Snee. and E. M. Taylor, Stratigraphic. sedimentologic, and petrologic record of late Miocene subsidence of the central Oregon High Cascades, Geology, 15, 389-392, 1987.

Snavely, P. D., Jr., H. C. Wagner, and D. L. Lander, Interpretation of the Cenozoic geologic history, central Oregon continental margin: Cross-section summary, Geol. Soc. Am. Bull., 91. 143146. 1980.

Stacey, J. S., and J. D. Kramers, Approximation of terrestrial lead isotope evolution by a two-stage model, Earth Planet. Sci. Lett.. 26, 207-221, 1975.

Stern, C. R., K. Futa, S. Saul, and M. A. Skewes, Nature and evolution of the subcontinental mantle lithosphere below southern South America and implications for Andean magma genesis, Rev. Geol. Chile, 27, 41-53, 1986.

Stern, R. J., S. H. Bloomer, P.-N. Lin, E. Ito, and J. Morris, Shoshonitic magmas in nascent arcs: New evidence from submarine volcanoes in the northern Marianas, Geology, 16, 426-430, 1988.

Tatsumi, Y., Migration of fluid phases and genesis of basalt magmas in subduction zones, J. Geophys. Res., 94, 4697-4707, 1989.

Tatsumi, Y., D. L. Hamilton, and R. W. Nesbitt, Chemical characteristics of fluid phase released from a subducted lithosphere and origin of arc magmas: Evidence from high-pressure experiments and natural rocks, J. Volcunol. Geotherm. Res., 29, 293-309, 1986.

Taylor, E. M., Volcanic history and tectonic development of the central High Cascade Range, Oregon, J. Geophys. Res., this issue.

Taylor, S. R., and S. M. McLennan, The Continental Crust: Its Composition and Evolution, 312 pp., Blackwell Scientific, Boston, Mass., 1985.

Verma, S. P., and S. A. Nelson, Isotopic and trace element constraints on the origin and evolution of alkaline and calcalkaline magmas in the northwestern Mexican volcanic belt. $J$. Geophys. Res., 94, 4531-4544, 1989.

Verplanck, E. P., and R. A. Duncan. Temporal variations in plate convergence and eruption rates in the Western Cascades, Oregon. Tectonics, 6. 197-209, 1987.

Walker, J. R., and H. R. Naslund, Tectonic significance of mildly alkaline Pliocene lavas in Klamath River gorge, Cascade Range, Oregon, Geol. Soc. Am. Bull., 97, 206-212, 1986.

Weaver, B. L., D. A. Wood, J. Tarney, and J. L. Joron, Geochemistry of ocean island basalts from the South Atlantic: Ascension, Bouvet, St. Helena, Gough, and Tristan da Cunha, in Alkaline Igneous Rocks, edited by J. G. Fitton and B. J. Upton, Spec Publ. Geol. Soc. London, 30, 253-267, 1987.

Weaver, C. S., and G. E. Baker, Geometry of the Juan de Fuca plate beneath Washington-Evidence from seismicity and the 1949 South Puget Sound earthquake, Bull. Seismol. Soc. Am., 78, 264-275, 1988.

Weaver, C. S., and S. D. Malone, Overview of the tectonic setting and recent studies of eruptions of Mount St. Helens, Washington, J. Geophys. Res., 92, 10.149-10,154, 1987.

Weaver, C. S., and C. A. Michrelson, Seismicity and volcanism in the Pacific Northwest: Evidence for the segmentation of the Juan de Fuca Plate, Geophys. Res. Lett., 12, 215-218. 1985.

Weaver, C. S., W. C. Grant, and J. E. Shemeta, Local crustal extension at Mount St. Helens, Washington, J. Geophys. Res., 92 $10,170-10,178,1987$.

Wells, R. E., and P. L. Heller. The relative contribution of accretion, shear, and extension to Cenozoic tectonic rotation in the Pacific Northwest, Geol. Soc. Am. Bull, 100, 325-338, 1988.

White, W. M., A. W. Hofmann, and H. Puchelt, Isotope geochemistry of Pacific mid-ocean ridge basalt, $J$. Geophys. Res., 92, $4881-4893,1987$.

Williams, D. L., D. A. Hull, H. D. Ackerman, and M. H. Beeson, The Mount Hood region: Volcanic history, structure, and geothermal energy potential, J. Geophys. Res., 87, 2767-2781, 1982.

Wood, D. A., A variably veined sub-oceanic upper mantlo-genetic significance for mid-ocean ridge basalts from geochemical evidence, Geology, 7, 449-503, 1979. 
Wyllie, P. J., Constraints imposed by experimental petrology on possible and impossible magma sources and products, Philos. Trans. $R$. Soc. London Ser. A, A310, 439-456, 1984.

Zoback, M. L., and M. D. Zoback, States of stress in the conterminous United States, J. Geophys. Res., 85, 6113-6156, 1980.

W. Hildreth, U.S. Geological Survey, 345 Middlefield Road, Menlo Park, CA 90425.

W. P. Leeman, Keith-Wiess Geological Laboratories, Rice University, Houston, TX 77251.
Z. Palacz, VG Isotopes Limited, Ion Path, Road 3, Winsford, Cheshire, CW7 3BX, England. N. Rogers, Department of Earth Sciences, Open University,
Milton Keynes, MK7 GAA, England.

D. R. Smith, Geology Department, Trinity University, San At tonio, TX 78284.

(Received May 11, 1989;

revised November 3, 1989;

accepted November 6,1989 .) 